\title{
Affects of Marshall Plan on Turkish Economy
}

\author{
Nurgün Koça, Bedriye Koça
}

\begin{abstract}
Marshall Plan is an important declaration that dominated world economy and politics after the World War II. It is also evidence that policy of the United States of America to make for its internal politics between two world wars was abandoned and it was intended to dominate world politics. Likewise, it can be considered as the smoking gun for power loss of continental Europe, including England, against the Soviet Union. When Turkey had to find its way into Western alliance in this new period divided into two poles and called as "Cold War", it intended to enter into economic acquis formed by Marshall Plan. Turkey, in the process to prevent the spread of communism against the Soviet Union that started mainly by Truman Doctrine, was of the first priority status by the USA just like Greece. It can be said that Turkish economy made an important progress to move into liberal system from its statist structure through Marshall Plan. Accession process to European Union integration mandated by the USA was started by Republican People's Party (CHP) and it was also continued in Democratic Party period with liberal program that took over the power as a result of elections in Turkey. Although Marshall Plan created economic added value in Turkey at the beginning, it could not create a sustainable welfare process as consultants coming from the USA had insisted on unilateral economic policies and Turkey was directed towards military spending due to being seen mainly as a buffer state against the Soviet Union and Middle East. It can be also said that arrangements arising from double standards in the application compared to European countries caused economic instabilities in the long run.
\end{abstract}

\section{Keywords}

Truman Doctrine, Marshall Plan, the United States of America, Turkey, economy

Marshall Plan that was demonstrated by the USA with intents to prevent European countries from moving into Soviet domination, rebuild the old continent destroyed by World War II, and invigorate the economy has been separately discussed and studied mostly as economy discipline or history discipline in Turkey. Main reason to start this study is that we determined that this method complicates the developments emerged from Marshall Plan to be understood. In that, to historian eyes, economic aspect of the issue cannot be demonstrated completely and also it can be perceived as useless economic knowledge as historical background of the issue and its effects on the society are deficient in terms of economic point of view. We think this complicated to understand sophisticatedly the process related to Marshall Plan. For this reason, we have tried to understand effects of Marshall Plan on Turkish economy from the view of history and business disciplines. Official publications provided by Turkish Republic, Prime Ministry General Directorate of State Archives have helped us to understand government policy on this regard and to ensure reliability for

\footnotetext{
aKarabük University, Turkey

Correspondent Author:

Nurgün Koç, Balıklar Kayası Location Iron and Steel Campus Karabuk, Turkey
} 
several numbers and statistics.

\section{POLITICAL AND ECONOMIC DEVELOPMENTS LED TO TRUMAN DOCTRINE AND MARSHALL PLAN}

Good relations that started with Truman Doctrine between Turkey and the USA began during power period of Republican People's Party (CHP) and the positive progress continued also during period of Democratic Party ${ }^{1}$ that had won the elections predominantly and took over the power.

According to General Alexandre Marshall, "Excellent strength of American democracy utilized everything available on the earth in order to ensure victory" (TRPMA, 30.1.0.0.56.344.30). It is possible to say that it acted in the same way after the war. While approaches of President Harry Truman to domestic and foreign politics were examined by Turkey's Washington Press Attaché on January 12 of 1948, it was emphasized on whether his messages in the Congress of January 7, 1948 were related to election competitions or not. Accordingly, Truman indicates that it is required to maintain supporting the United Nations in order to establish world peace based on the principles that will secure liberty, justice, and equal rights for all nations as regards foreign politics. Similarly, all nations, involved in West Block notably the USA, have made efforts to develop world trade (TRPMA, 30.1.0.0.101.625.14).

European countries that had experienced a widespread devastation due to World War II encountered with important economic and social problems. The most important of them is that they had a difficulty with dollar because they were forced into importing widely from the USA. Thus, these countries tried to find loan by applying to the USA separately. The USA thought that loan to be made in this way would not be favorable and that it would be more favorable if European countries created an economic cooperation to help each other and if American assistance $^{2}$ was made within the scope of this corporation and under control. George C. Marshall, Minister of the Foreign Affairs of that period, called the European countries for an invariable corporation and assistance to each other by means of his speech on June 5 of 1947 (TRPMA, 30.1.0.0.125.801.5).

According to famous Senator Vandenberg, who showed legally and politically an important support in formation of Atlantic Pact, it was seen in 1948 that political stability in Western Europe was much more important than assistance in American dollar. Union of Soviet Socialist Republics met Marshall Plan with the threads of Cominform and censures of Molotov. More importantly, the Soviets went too far to the extent that they blockaded Berlin at the beginning of March in order to separate it from Western occupied region. They were planning to eject Western countries from Berlin and make the peace doubtful and unstable. Events in Czechoslovakia, war against Finland, efforts of communists in Italy and France to seize power, and conditions in Greece and Turkey were leading doubts concerning real intents of Russians. Russian delegate had tried to interrupt the works by applying for veto 23 times in the Security Council. In this case, it is seen that a series of decisions were made during American congress based on strengthening the United Nations Organization but when examined, they were wrong decisions contrary to this. Among these decisions, we encountered some recommendations such like federalization of Western Europe, world government, abolition of veto against the aggressor, and rewriting Constitution of the United Nations. Other development leading to concern was that the pessimist thought of Ministries of Defense and Foreign Affairs that America was debilitated due to Russian action and armament. Just as Western occupation countries in Germany were destitute of the capability to meet a Russian strike, Western European countries also had a complete weakness of military, other than American weapon, against possible attacks that could be from the East. Under these circumstances, England, France, 
and Benelux countries concluded a military and economic corporation treaty for 50 years in Brussels, in March 1948. On the day the agreement was signed, President Truman stated: "I believe that we will meet self-protection tenacities of independent countries in Europe with the same tenacity to provide assistance for them" (Erkin 1992: 26-28).

In the period following World War II, it was obstructed to put Yalta and Postdam decisions into practice. The Soviet Union began to exercise sovereignty directly on certain Eastern Europe countries to which they had promised free election and soon afterwards they headed for the West. Thereupon, America that did not hesitate to help Europe countered Russian challenge with Vandenberg Decision which accelerated North Atlantic Regional Alliance to show up. Besides, by putting Marshall Plan into effect, it did not abstain from using its resources to invigorate economic and industrial activities which would have brought the old continent up to the level that could compete even with itself one day (Erkin 1992: 37).

It is seen that moves for peace and liberty gained speed when Truman assigned General Marshall ${ }^{3}$ to the Minister of Foreign Affairs. Common political attitude was to prevent spread of communism to the countries that came up against the thread of spread of communism through either military attack or poverty and to help development of these countries through "containment". Truman Doctrine, Marshall Plan, North Atlantic Pact, and Fourth Point are moves that one each is revolutionary and has the same purposes after the war and in American political life (Erkin 1999: 543).

In fact, assistance was provided from America to Europe during the war. Many European countries, notably England, were supported by military materials at 50 billion-dollar value via "Lend and Lease Act". Turkey, despite being neutral, received military support at 95 million dollars by these assistances, and benefited from the assistance of the $\mathrm{USA}^{4}$ through England despite the occasional interruptions (Topal
2013).

According to the report submitted by General Marshall when he was Chief of the Turkish General Staff to the Department of War, changes of place and board opportunities even for Chinese Red Army were increased further through American locomotives and railway equipment in addition to military article assistances supplied at significant amounts to the Allies such like England, France, and the Soviet Union during World War II in accordance with the provisions of lend and lease. Mutual assistance benefited from the Allies was mainly composed of residence facilities, base equipment, and food items. In terms of food items, America was supported with food by 218 million kilos from England, 800 from New Zealand, 835 from Australia, and 524 from India (TRPMA, 30.1.0.0.56.344.30).

It was sought to find a more efficient solution when assistances provided by the USA for development of and escaping of Europe from thread of the Soviet were found insufficient. George Marshall, Minister of Foreign Affairs, in the light of reports submitted to him $^{5}$, after the plan was explained with his speech in Harvard University on June 5 of 1947 (Yücel 2001: 67), gathered Ministers of the Foreign Affairs in England ${ }^{6}$ and France in Paris on June 16 of 1947 and convoked the Soviet Union to this meeting. As the Soviet Union attended the meeting but maintained a negative attitude, this conference of three left on July 3 without any conclusion. Thereupon, England and France invited all European countries on July 12 and Spain was left aside. The Soviet Union and their follower countries did not attend this conference and it was called " 16 's conference" due to the number of countries attended. In fact, in the conference of which member number reached 19 with the participations from three German regions, a four-year development programme was designed for Europe and then a report was prepared concerning the amount of assistance required to be provided by America to Europe. This report formed the basis of 
American reports constituting basis of the assistance approved by American Congress (TRPMA, 30.1.0.0.125.801.5).

Thus, "Organization for European Economic Cooperation" (Organisation Europeenne de Cooperation Economique-OECE) was constituted; Austria, Belgium, Britain, Denmark, Ireland, France, Greece, Iceland, Italy, Luxemburg, Holland, Norway, Portugal, Sweden, Switzerland, and Turkey were involved in the frame of Marshall Plan. The USA did not implement this policy not only in Europe, by using atom bomb in Japan, it created a set southeast of the Soviet Union after World War II ended. "The USA provided Japan with assistance in that castle. It obliged Japanese goods to be sold to the USA. The first goal of new plan was to create a block against the spread of communism" (Ünsal 2011).

\section{REGULATIONS CONCERNING IMPLEMENTATION OF MARSHALL PLAN}

Within the frame of plan, Organization for European Economic Cooperation was constituted on April 16 of 1948 and Turkey became a member of the cooperation when the Law dated July of 1948 and no. 5252 was approved by the Assembly. One Council and one Executive Committee of the Cooperation were formed. Operation is generally like this (TRPMA, 30.1.0.0.125.801.5):

Council is composed of the participant countries and decisions are made with alliance. It is required to implement the decisions made with the alliance by all member countries. However, one of the members might abstain by suggesting that it is not associated with certain decisions. In this case, other countries have to abide by the decisions made with the alliance. Council selects one President and one Deputy Chairman among the members every year.

Executive Committee is composed of seven members selected by the Council every year. Turkish Government made an effort to see Turkey or Greece as member in this Committee and became successful. The first year Turkey and the following year Greece were represented in the Committee. As well as it has one Secretary General and Secretariat, a Credentials Committee of four was constituted with the President of the Council as a result of a decision of Council made.

Duty of the cooperation is to make decisions that would provide economic development of the participant countries, examine the programs they would prepare, and ensure the coordination among them by giving an opinion about these programs. Council early on had made decisions on uniform programs prepared by each government, determined American assistance required to provide for each country, and ensured coordination. Later on, however, American authorities determined the amount of assistance and distribution to the countries. As American financial year starts on July 1 and ends on June 30, programs are submitted to Organization for European Economic Cooperation at the beginning of May. The organization carries out the examinations by means of technical committees formed within its body and submits its opinions on each country's program to the Executive Committee and then these opinions are transmitted to the Council and finally American Economic Cooperation Administration (ECA). This procedure is the standard working style of the organization and a number of changes may appear from time to time.

American assistance presents the obligation for every country to prepare a four-year long-term development programme and to revise it every year. After the programs are approved by ECA, it is time to actual assistance and so order and purchase processes start as government knows about the dollar they would receive and where this fund would be used. In order to start actual expenditure, every country makes a Borrowing Contract with Export-Import Bank that acts in behalf of the USA Government for the direct assistance provided by loan and one each bill is 
issued.

Assistances provided by the USA within the frame of Marshall Plan are provided in two ways as direct and indirect assistance. In the memorandum of Turkish Republic prepared concerning the implementation of Marshall Plan in Turkey that was prepared by Organization for International Economic Cooperation, detailed information related to the assistance types is presented. According to this:

(1) Direct assistance: These are dollar assistances granted to meet the import from the USA or dollar area. Indirect assistance: These are assistances granted to meet import and purchase from the participant countries. It has three types as loan, grant, and conditional aids. Credit is in the form of long term and by $2.5 \%$ interest loan. Grant and aids are the voluntary assistances from the USA. As for conditional aids, they are composed of the assistances received from the USA in dollars in return for clear circulation rights accorded by a participant country to other participant countries between the periods of 1948-1949 and 1949-1950.

(2) Indirect assistance: At the beginning, it was provided as circulation right, creditor starting balance, quota and private sources. The USA exports goods to Europe through the assistances provided as loan or grant and also it executes technical assistances and certain services. As the participant countries preferred the USA goods - assistances as loans or grants - to European goods purchased by cash, industrial countries were therefore damaged as well as tobacco and dried fruits and consequently Turkey were damaged and it caused to criticisms. Afterwards, circulation right formula was suggested when it had been seen that countries the USA tried to develop had difficulty in exporting in this way. Accordingly, the principle to receive circulation right was suggested, that is, the principle is to examine balances of general payments between the participant European countries and others and, if there is favorable deficit, namely activity, to provide a payment and solvency in its own national currency and on its own market to the extent that this deficit is met for the one with liability by the one having active condition; and if there is unfavorable deficit, namely liability, to provide a payment and solvency from the active country to itself to the extent to meet this deficit to be used on the market in that country's national currency. The USA executed conditional dollar allocations in return for gross amounts of circulation rights provided in this way. Allocations for the countries having circulation rights were conditional upon use of these circulation rights by the countries receiving their circulation rights. In some cases, allocations were practically executed earlier. As for Turkey, as an exemption, allocations between 1948-1949 were executed upon the difference between the given and received circulation rights, not the sum of gross circulation right (TRPMA, 30.1.0.0.125.801.5).

Circulation rights were conducted in accordance with Payment and Compensation Agreements signed between the European countries on October 16 of 1948 and September 7 of 1949. These agreements provided a common accounting method to execute processes conducted upon several funds and also allowed mutual deficits and surpluses of the parties to be paid by means of the circulation rights. Circulation rights were based on the deficits to occur in balance of payments for a given period. Member countries were forced to accrue the deficits estimated at the beginning as the non-used circulation rights would be cancelled at the end of the period and therefore they were prompted to have a deficit in balances of the payments. Since the end of 1949, it was adopted to have a gradual sovereignty in the changes between European countries in order to develop commerce between the countries and make prices lower by determining the free competition conditions again. And it was required to remove the possible threads in order to make the change free, transform the funds to each other easily, and provide the facilities of payments. For these reasons, taking into consideration the experiences 
obtained by the execution of Payment and Compensation Agreements, "European Union of Payment" was formed by an agreement signed between the member countries on September 19 of 1950. This agreement was approved by Grand National Assembly of Turkey with the law dated August 1, 1951 and no. 5824 (TRPMA, 30.1.0.0.125.801.5).

Belgium and ECA Administration, namely the USA, asked circulation rights to be convertible into dollar and transferable to each participant country and the USA, however, England objected to it and suggested that only commerce would be practiced gradually between the participant countries without limitation. After strong discussions, it was accepted that conditional American dollar allocations required to be supplied at the rate of transfers to be performed accordingly which was proposed by the French and that $25 \%$ of the circulation rights required to be transferable only within the participant countries. In accordance with this propose, if any participant country does not use $25 \%$ of the circulation right received by any country due to certain reasons such like high prices in that country, then it can transfer it to another participant country. Dollar corresponding to the amount transferred with this transfer will devolve as a conditional aid for the country to which transfer has been made (TRPMA, 30.1.0.0.125.801.5).

Circulation right was an application conducted within the scope of economic cooperation which European countries used when they give and receive goods within themselves. Goods that could not be bought due to the foreign currency shortage could be thus supplied. The country that would buy products paid the price of that product in a national bank as "Contingency Fund". In point of fact, it is noticed that this money in the fund becomes a grant or a loan of money as it would be used in the project for that country although it seems to be purchased at its own expense. It is understood in the discussions between the countries mentioned above that circulation right is not in fact a functional method. Reactions were caused as the country having circulation right was forced to purchase at high prices and thus transfer of the circulation rights became an issue. We encounter another problem that non-used circulation rights would be cancelled. Transfer of circulation rights has eliminated this problem even a little.

The USA provided assistances to certain countries owed intrinsically to European Union of Payment through the basis of loan and grant in the name of starting balance. Turkey received 25 million dollars as starting balance. This assistance is in the form of debt. It is 15 -year term and by $2.75 \%$ interest. The 15 -year period shall start since the termination of the agreement. The 50 million-dollar creditor and debtor quota was inherited from European Union of Payment to Turkey. Turkey, due to its own condition, could not bring its commercial sovereignty beyond $60 \%$ while import should have been by $75 \%$ (TRPMA, 30.1.0.0.125.801.5).

It was paid attention to introduce Marshall Plan to the public and thus it was propagated. American Murray Martin states that this plan should be explained to 18 countries in total including 16 countries and the USA involved in Marshall Plan and also the Soviet Union, if they desire. He states that they do not know if this plan can save the world, however, neither Marshall Plan nor a different measure could be deemed successful if it was not supported voluntarily by the majority of people and he also says that the most effective method is radio broadcast. In this respect, it was recommended to allocate all world radios to introduction of Marshall Plan for 24 hours. In this way, it might be ensured that millions of people would pay attention to this issue and the required announcement would be made (TRPMA, 30.1.0.0.5.23.11).

It was benefited from cinema for the introduction of plan and several films were made. Movies about Marshall Plan were prepared by Europeans in the Europe and for Europeans and financed by European 
governments. In America, it was forbidden as being considered as propaganda means. Sandra Schulberg states that these movies were displayed by him in 2004 for the first time. It was understood that at least 300 movies were made. The movie made for Turkish people is "Yusuf and Sabanı" (Schulberg and Toprak 2008).

\section{TURKEY AND MARSHALL PLAN}

\section{Attempts of Turkey That Was Intended to Be Kept out of Western Europe Integration}

According to Ankara Alliance on October 19, 1939, obligation of Turkey to attend World War II came into question for the first time after Germany attacked France in May of 1940 and Italy declared the war against France. In this way, the war spread around the Mediterranean and Turkey had to go to war in accordance with the 1st article of the agreement made with England and France. Turkey did not do that, more precisely, Turkey could not do that because of attitude of the Soviet Union. When the issue was brought to the Soviets abiding by 1925 Agreement of Turkish-Soviet Friendship and Non-aggression, the Soviet Union threatened Turkey to not go to war. According to protocol no. 2 of the alliance, Turkey was not obliged to take sides with the Allies in this case; so that, England and France did not insist Turkey on going to the war (Armaoğlu 1993: 407).

The Soviet Union pronounced Kars and Ardahan to be returned to them through two memorandums given to Turkey on March 19 of 1945 and June 1 of 1945. At the same time, they wanted to become a partner with Turkey to defend Istanbul and Çanakkale Straits. Turkey rejected the Soviet memorandums immediately. At that point, Greece was under the thread of communism. In civil war of Greece, there was a thread concerning that Moscow would occupy Greece and reach the Mediterranean. The Soviets tried to enable communist parties to come into power by interrupting their national economies through general strikes by means of using another tactics in Italy $^{7}$ and France. America that was aware of all these threads provided more than 50 countries with 15 billion dollars from June 30 of 1945 to the late of 1946. However, Greece and Turkey were kept out of these assistances. Therefore, president of the USA, Truman proposed an immediate assistance for Turkey and Greece through the bill of law called Truman Doctrine. While assistance package in question was discussed in Chamber of Deputies, according to the air formed against Turkey, "assistance would be provided to protect the democracy. Yet, there was military dictatorial regime in Turkey" (Yücel 2001: 66).

In Cold War, integration would turn Western Europe community into Atlantic community in the leadership of the USA. Assembly of Marshall Plan, European Assembly, and Atlantic Group were three political branches in Western Europe. Indeed, this group of three caused doubts in minds concerning the scope of integration. If the cooperation was deemed in terms of Marshall Plan or European Assembly, then Turkey would enter into the cooperation in the frame of economic cooperation. If the cooperation was considered only as turning into Group of Atlantic Pact, then it was required to consider European Council as a theoretical structure. According to certain news on the newspapers, it was decided to restrict the American assistance by Atlantic Pact criterion which it would continue after Marshall Plan ended. The decision, regarded as satisfactory through placing Turkey into a community that would benefit from American assistance resource, appeared like "a new game" that would take it out of Western community and integrate its destiny with weak and unstable Middle East (Erkin 1992: 182).

Minister of English Foreign Affairs, Ernest Bevin, was cool towards the participation of Turkey in "Western Europe Union". He stated that American military guaranty of Western European Union discussed in Washington is not required to include 
Turkey that is at highly satisfactory level in terms of American assistance (Erkin 1992: 17-18). Besides, it was thought concerning which countries would be involved in Atlantic Pact that it could be unfavorable if the commitments brought along the advantages of acceptance to the Pact would spread around extremely far regions, and at the end of this comparison, it was made a decision regarding that Turkey and Greece were not accepted due to the distances. But they especially stated it would not decrease their determinations to support sovereign rights and territorial integrities of Turkey, Greece, and Iran (Erkin 1992: 44).

Under these conditions, an obligation emerged naturally for transition of Turkey to a multi-party system, and efforts of President of the Republic, İsmet İnönü, on this regard are important:

It can be said that National Chief İnönü played an effective role in transition to a multi-party system. It can be indicated that İnönü, who read well both internal and external conditions, featured his quality of foreseeing statesmanship and didn't prevent the course in this direction in fact even though he didn't mainly subscribe to transition to a multi-party system. It is matter required to be highlighted that internal factors are effective for transition to a multi-party system but the main determinant is the change in external factors. Almost all change and modification actions implemented since the Tanzimat reform era was performed taking the developments in the external world into consideration. (Akıncı and Usta 2016: 286)

Even though Turkey relieved to a certain extent through announcement of Truman Doctrine and then July 12 of 1947 Agreement $^{8}$ signed within the frame of this doctrine, it needed capital in order to improve itself economically later on. Turkish Government regarded Marshall Plan as a means for development of Turkey, attended the Conference of Economic Cooperation gathered in Paris, and demonstrated its will to attend common cooperation for the development within the ambiance of cooperation estimated by Marshall Plan. Detailed information was presented on economic conditions of the country and an assistance of 615 million dollars was requested within the frame of Marshall Plan in order to execute economic development programme which was prepared after the war (Ünsal 2011).

As the USA, after the speech of Marshall on June 5 of 1947, stipulated European countries to establish cooperation and help each other in order to provide assistance for them, every country which wanted to utilize American assistance had to be involved in Organization for European Economic Cooperation and sign an Agreement of Economic Cooperation with the USA. For this reason, Turkey signed Agreement of Economic Cooperation with the USA on July 4 of 1948 and submitted to approval of Grand National Assembly of Turkey on July 8 of 1948. Agreement was completely accordant with the agreements concluded between other countries and the USA. According to terms of the agreement, Turkey would act in accordance with the objectives of Organization for European Economic Cooperation and the USA would help Turkey to the extent approved by its laws. Turkey accepted to enable ECA representatives in the America to work in Turkey and to grant diplomatic privileges (TRPMA, 30.1.0.0.125.801.5).

President of the Republic, İsmet İnönü stated in his speech after Truman Doctrine was accepted that American assistance was an important action to maintain democracy and relations ${ }^{9}$ to be established well between Turkey and the USA would facilitate to place democracy in Turkey in a reliable sense (Yücel 2001: 67). As shown in Appendix 1, President of the USA, Truman, presented sincere congratulations of American people and him and gave warm wishes to Turkish people and İsmet İnönü through a speech prepared for Ankara radio concerning 25th Anniversary of Turkish Republic, and he stated in the America that they admired from the beginning Turkish people for their determined struggle in the unbending leadership of Mustafa Kemal Atatürk. Truman, indicating that political independency and 
territorial integrity of Turkey were of capital importance in terms of safety in America and all freedom-spirited peoples, stated that he made effort to enlarge the assistance presented to Turkey and Greece in this regard and that time of assistance program was extended until July of 1949 as being one year since his suggestion was accepted by American Congress.

Above all we are happy one more time that Turkish people continue to implement the decision to develop its democratic issues and support these ideals with which American people were bonded at heart in such a case human rights and liberties are violated and invalidated so unmercifully in many parts of the world. (TRPMA, 30.1.0.0.101.624.13)

Council of Minister decided on July 15, 1948 to establish "Committee for American Loans" affiliated to the Prime Ministry as being responsible for affairs related to the assistance within the scope of Marshall Plan and other American loans. Committee fulfills the instructions given by the Minister assigned by Prime Minister and the duties mentioned in Articles 6 and 7. Committee is composed of a President and Deputy President and also specialists allocated from the Ministries of Agriculture, Transportation, Economy, Finance, and Public Works. Duties of the committee for American loans are:

(1) To prepare plans concerning the loans to be requested in compliance with opinion of government;

(2) To collect and send details to be requested by the United Nations European Council of Economics, Organization for European Economic Cooperation, and American Assistance Administration, perform and conduct local and foreign negotiations to be made, and defend the requests of Turkey in the presence of proper foreign authorities;

(3) To take precautions to prevent use of the allocated assistances for the wrong purposes;

(4) To follow works conducted concerning the assistances and inform the relevant departments from time to time;
(5) To give information asked by American commission to be formed in Turkey and establish a connection between the ministry and departments regarding the mission;

(6) To execute all other works concerning Marshall Plan (TRPMA, 30.18.1.2.116.48.10).

Committee, excluding the duties mentioned above, is responsible for the following duties regarding International Development and Reconstruction Loan and other loans required by our development programmes:

(1) To prepare projects regarding works involved in our development programmes and send them to International Development and Reconstruction Bank;

(2) To collect and send details requested by the Bank;

(3) To follow investigations in Turkey of mission to be sent by the Bank to Turkey and establish the connection between departments concerning this work;

(4) To execute necessary negotiations in the country and abroad (TRPMA, 30.18.1.2.116.48.10).

Committee will be also responsible for all duties required to be executed in the country and abroad concerning the external financing of our economic development program. Expenses will be undertaken by State Economic Associations assigned by the Minister of Economy. "All Public Offices and State Economic Associations are responsible for submitting all kinds of information and providing all kinds of association asked by the committee". President of Republic, İsmet İnönü, approved the decision made by Council of Ministers (TRPMA, 30.18.1.2.116.48.10).

Secretary General of the Ministry of State, Fatin Rüştü Zorlu, was empowered to sign, on behalf of Turkey, requisitions concerning Marshall Assistance (202), technical assistance requisitions and allowances in the contacts established with United Nations Administration for Economic Cooperation and Organization for European Economic Cooperation, and President of Republic, İsmet İnönü approved them 
after being acknowledged by Council of Ministers on December 15, 1949 (TRPMA, 30.18.1.2.121.87.17). Along with political table changed after the elections, it was decided in the meeting of Council of Ministers dated June 12, 1950 to empower Bülent Yazıc1, First Head of Department of Prime Ministry International Organization for Economic Cooperation, who was responsible for subjects concerning Marshall Assistance in the contacts established with United Nations Administration for Economic Cooperation and Organization for European Economic Cooperation, and it was approved by Celâl Bayar, the President of Republic, as shown in Appendix 4 (TRPMA, 30.18.1.2.123.49.14).

Discussions started in Turkish press as well as starting of the assistances ${ }^{10}$, and majority supported American assistances and negative criticisms were rare.

Turkey was provided with assistances within the scope of Marshall Plan which is in two ways like for other countries. First was direct assistance that was provided for Turkey through dollars and used in purchasing goods and services from the USA. As for the second one, it was the purchase opportunities provided by several European countries to Turkey as circulation right (TRPMA, 30.1.0.0.80.507.5).

\section{Criticisms Concerning Turkey}

Before Marshall Plan was submitted to the American Congress, England, France, and Italy started to prepare their development and reconstruction programs accompanied by the plan and gained a lot of money benefited from services of American companies for Financial and Economic Planning in order to make the convenience easier. At the beginning, important losses took place since Turkey did not possess such a plan available and then efforts made in this regard were not enough to close the gap between European programs and Turkey (Erkin 1999: 374-375).

Even though it was notified therefore that Turkey would not be provided with assistance for 1948-1949 years, assistance of 49 million dollars was provided upon the attempts made. Again in the same way, even though it was notified that Turkey would be provided with only 30 million for 1949-1950 years, this amount was increased up to 59 million upon the disapprovals from Turkey. Turkey made two Borrowing Agreements with Export-Import Bank, on behalf of the USA government, for 1948-1949 years and one was at 30 million and the other was at 38 million substituting the first one. Turkey signed one Borrowing Agreement of 36 million dollars, as one million for technical assistance, for 1949-1950 years. In this way, Turkey received direct assistance, for these two periods, in a loan of 74 million dollars within the scope of Marshall Plan. The 38 million-dollar part of these Borrowing Agreements was approved by Grand National Assembly of Turkey through the laws of December 24, 1948 and no. 5282 and of March 25, 1949 and no. 5359 and 36 million-dollar part was submitted to the approval of Assembly (TRPMA, 30.1.0.0.125.801.5).

While Turkey was provided with only assistance as borrowing at the beginning, Economic Cooperation Agreement of July 4 of 1948 was updated on January 31 of 1950 via an additional agreement involving the assistances in grants by making an attempt to utilize assistances in grants. In accordance with this agreement, Turkish funds corresponding to the assistances received in grants would be deposited into the two bank accounts which were named after accounts of $95 \%$ and $5 \%$ and kept at the Central Bank. As for money into these accounts, account of 5\% would be spent for expenses of ECA Administration in Turkey and money into the other account would be used for the purposes to provide financial consistency with the agreement of both countries, develop Turkey economically, or increase the military power (TRPMA, 30.1.0.0.125.801.5).

In this process, committee of a large number of experts came to Turkey to evaluate Turkey's offer of 
assistance from the USA and examine on site, and they prepared several reports ${ }^{11}$.

For example, when Turkey submitted a loan request to Central Bank in 1948, the Bank created a committee to see economic and financial status on site. Head of the committee, Mr. Mason coming from Turkey summarized his observations as the following: Turkey is an untreated country with great opportunities. Due to the financial difficulties, export is required to be increased. It should be started immediately to export fruits which are delicious and rich in varieties and unique all around the world. Fruit $^{12}$ and fish ${ }^{13}$ are the first goods to be considered. It would not be correct to ignore the available opportunities and chase for big projects. It is seen that etatism in Turkey is proper in general as well as it is exaggerated and private sector is startled. Private sector, therefore, had to engage in merchandise instead of heading towards effective economic areas. It is required to enable private equity attempt by decreasing etatism to an extent. In addition, he stated that they found important coordination deficiencies in the projects of Turkey involving port and road building and that they could not encounter any agreeable coordination even in the same ministry. Mr. Knudson, one of the chiefs of Marshall Plan, also stated by the same criticism that lack of coordination between the ministries created disappointment in the recession seen in economic development area. Another concerning issue is that there were hesitations in terms of approval of Sariyer Dam project due to lack of internal financing. "Finally Marshall Plan Administration is of opinion that welfare in Turkey largely depends on development of tourism" (Erkin 1992: 59-61).

Senators coming from the USA to Turkey in the later 1949 considered especially subjects regarding etatism, security of foreign capital, and use of American allocations, and insisted on especially the subject that 1945 Export-Import Bank loan was not be used still. When ECA explained rates to use supply of goods licenses in the countries of Marshall Plan, rates were $83.50 \%$ in England, $68.30 \%$ in Greece, and $19.10 \%$ in Turkey. Erkin states that this low rate caused new comments against us (Erkin 1992: 118).

Program of 1948-1949 years was not clear and suitable for the truths according to the American criticisms towards Turkish bureaucrats within the frame of Marshall Plan. It was stated that number of the experts with quality to prepare the program was very few; an excellent program could not be prepared like other countries had; articles subject to license were involved in the program in export due to the shortage; needs were exaggerated; and that an exception could be made for the exaggerated amounts if they remained by $30 \%-40 \%$ but they exceeded this rate and therefore all items aroused suspicion, etc. "Even though our administration asked in our program to increase production especially for chrome, manganese, and lead and to involve fish, fruit, and vegetable industries, this request has been ignored. Under these conditions, it is not possible to use the loan allocated to you until the end of financial year". Erkin states with sorrow that this condition is unfortunately an ugly truth and we could not benefit from large opportunities possible to be easily opened for Turkey since we prepared unscientific and random programs in our relations with ECA and that we were stranded while other countries shared loans and grants abundantly. While talking about the difficulties experienced within the frame of execution of Marshall Plan that even though he left tired but with a little hope at the end of tough meetings lasting long hours, unrest did not end as he was worried about problems that seemed as if impossible to deal with, it would continue (Erkin 1992: 107-112, 131-132).

\section{Assistances Provided for Turkey}

It is shown distribution of direct and indirect assistances in Table 1-Table 9.

In Turkey, as being different from most of member countries, the large parts of assistances were 
allocated to several development areas such like agricultural mechanization, treatment of the underground sources, modernization of the businesses available, investments related to energy sources, main road construction, improvement for means of transport, and the remaining part was used to supply consumer goods sometimes seen as urgent need. It is extremely important to increase military power and support it by reinforcing sector of economic activity. For this reason, most of the recent allowances have been allocated to military area (TRPMA, 30.1.0.0.125.801.5).

According to information submitted by Deputy Prime Minister, Faik Ahmet Barutçu, to Prime Minister, Hasan Saka, agreement draft introduced regarding loan of 30 million dollars to be provided for Turkey by Marshall Plan for the last nine months of 1948.

Provisions of this draft reiterate the provisions of loan terms submitted from our Washington Embassy on 18th August but it is seen that order date is enlarged until 30th June of 1949 in our favor. There is no other change. (ECA) confirmed to our Washington Embassy that amount of 30 million dollars does not mean any reduction in the amount of 60 million dollars mentioned for the fifteen-month period between 2nd April of 1948 and 30th June of 1949. (TRPMA, 30.1.0.0.111.700.14)

Balance of 3,098,000 dollars that was not attached to permission of supply from direct assistance allocation in the period of 1949-1950 was attached to permission of supply in the period of 1950-1951. Assistance of 24 million dollars was received in the period of 1951-1952 for two million direct and 22 million indirect assistances. Allocation amount of that period was not exactly specified, and it has been estimated that it was higher than the amount provided so far (TRPMA, 30.1.0.0.80.507.5).

In August 1949, as shown in Appendix 3, it was decided to send Cemil Parman, General Director of
State Marine Lines and Behçet Osmanağaoğlu, Deputy General Director, to Paris to get in touch with our Paris committee and Italy, Holland, and other European countries when necessary in order to discuss the order opportunities and conditions of ships to be supplied from European countries via Marshall Assistance and this decision was approved by the President of the Republic, İsmet İnönü (TRPMA, 30.18.1.2.120.60.2). In June 1950, Council of Ministers decided to supply locomotive reserve, motor driven trolley and bulldozer, which would be purchased by the fund allocated by direct assistance of Marshall Plan to General Operation Directorate of State Railways and Ports, providing that an agreement would be entered into directly with owners or representatives of the companies, without any broker or intermediary, and contract guaranty or liquidated damages for delay would not be sought; that it would be accredited up to hundred percent and advance would be given up to the same amount in order for paying the fee in return for shipping papers if it is impossible to pay material fee in any other way or in return for providing evidence that materials are ready for shipment at the factory if it is also impossible in this way; and that price increases associated with the conditions such like raw material and labor would be paid attention during the shipment of the material, and this decision was approved by the President of the Republic, Celâl Bayar (TRPMA, 30.18.1.2.123.56.9).

The $42.6 \%$ is the rate of amount allocated to private sector through total association. A part of 784,000 dollars within the balances of import credit allocated to agriculture in the period of 1948-1949 was transferred to the period of 1950-1951. Even though the period of 1949-1950 is seen as 55,405,000 dollars, 59,000,000 dollars were allocated in fact. Allowances of supply at 3,098,000 dollars were received in the period of 1950-1951 (TRPMA, 30.1.0.0.80.507.5). 
Table 1. Distribution of Direct and Indirect Assistances in 1948-1949 and 1949-1950 Periods (000 £)

\begin{tabular}{llll}
\hline & $1948-1949$ & $1949-1950$ & Indirect \\
\hline Agriculture & Direct & Direct & 1,411 \\
Public works & 22,148 & 14,013 & 1,060 \\
Water works & - & 400 & 251 \\
Highway & 5,000 & 9,000 & 3,500 \\
Directorate of Railways and Ports Construction & - & - & - \\
Health & - & 850 & 6,951 \\
Transportation & & 609 & 11,758 \\
Maritime lines & - & 300 & 1,680 \\
Railway & - & - & 12,853 \\
Businesses & & 8,752 & - \\
Sümerbank & - & - & - \\
Etibank & 18,881 & 300 & 6,100 \\
Customs monopoly & - & 800 & - \\
Statistic & - & 1,540 & 27,817 \\
Map & - & 13,821 & - \\
Soil office & & 5,520 & 74,221 \\
Meat and fish & - & - & \\
Wheat & - & 55,405 & \\
Economy and commerce & & & \\
Market & - & & \\
Petrol & 2,971 & 49,000 & \\
Sum & & & \\
\hline
\end{tabular}

Note: Source: TRPMA, 30.1.0.0.80.507.5.

Table 2. Distribution of Assistances in 1950-1951 Period

\begin{tabular}{ll}
\hline Direct assistance (45,000,000 dollars) & $£$ \\
\hline Ministry of Agriculture (Agricultural implements and machines, service vehicles seed, and agrochemicals) & $8,501,000$ \\
National defense & $13,822,000$ \\
Etibank & $1,236,000$ \\
Zonguldak basin & $3,682,000$ \\
Energy transmission line and Sariyer Dam & $4,500,000$ \\
Ministry of Public Works & 801,000 \\
Highways & 60,000 \\
Airports & $1,644,000$ \\
Electrical etude works & 795,000 \\
Ministry of Health and Social Assistance (struggle with malaria) & 210,000 \\
M.T.A. & 387,000 \\
Private enterprise & 61,000 \\
Hilton Hotel & $9,301,000$ \\
İbrahim Ethem Ulugay chemical house & $45,000,000$ \\
Istanbul cement factories & \\
Ministry of Economy and Commerce (trucks, truck reserves, rubber tires, machine reserves, tin, mine pole, \\
agrochemicals, carriage, newsprint) & $4,560,000$ \\
Sum & $1,360,000$ \\
Indirect assistance (25,000,000 dollars—starting balance) & $1,680,000$ \\
State marine lines (in remuneration for installments of ships ordered last year) & 495,000 \\
State railways (for locomotive spare parts purchase) & $16,905,000$ \\
Sümerbank (in remuneration for installments of Karabük Kok and Sinter plants) & $25,000,000$ \\
Monopoly (for operating supplies of salt works) & \\
Etibank (construction of Sariyer Dam, purchase and installments of arrangement materials for Zonguldak and & \\
Western lignites) & \\
Sum &
\end{tabular}

Note: Source: TRPMA, 30.1.0.0.80.507.5. 
Table 3. Distribution of 252,221,000 Dollars Received by Marshall Plan in the Periods of 1948-1949, 1949-1950, and 1950-1951

\begin{tabular}{|l|l|}
\hline Ministry of Agriculture & $46,123,000$ \\
\hline Ministry of Public Works & $24,572,000$ \\
\hline Ministry of Health and Social Assistance & $2,494,000$ \\
\hline $\begin{array}{l}\text { Ministry of Transportation } \\
\text { State marine lines } \\
\text { State railways }\end{array}$ & $12,120,000$ \\
\hline $\begin{array}{l}\text { Ministry of Businesses } \\
\text { Etibank } \\
\text { Sümerbank } \\
\text { M.T.A. }\end{array}$ & $13,418,000$ \\
\hline Ministry of Customs and Monopoly & $62,475,000$ \\
\hline Statistic and map works & $3,360,000$ \\
\hline National defense & 795,000 \\
\hline Projects of private enterprise & $1,335,000$ \\
\hline Ministry of Economy and Commerce & 500,000 \\
\hline Projects of meat and fish & $13,822,000$ \\
\hline Market (several import materials) & 658,000 \\
\hline Carriage & $7,644,000$ \\
\hline Sum & $60,805,000$ \\
\hline
\end{tabular}

Note: Source: TRPMA, 30.1.0.0.80.507.5.

Table 4. Shares of Public and Private Sectors in General Collection

\begin{tabular}{|l|l|}
\hline Private sector & $46,123,000$ \\
Agricultural implements and machines & 658,000 \\
Projects of private enterprise & $60,805,000$ \\
\hline Several imports for the market & $144,635,000$ \\
\hline Public sector & $252,221,000$ \\
\hline Sum & \\
\hline
\end{tabular}

Note: Source: TRPMA, 30.1.0.0.80.507.5.

Loans given to the private sector ${ }^{14}$ have spread on a large area from works of draining lands and swamps to hotel construction.

One of the assistances provided for Turkey is technical assistances. Experts required for economic development were imported from the USA and it was benefited from their knowledge and experiences. This assistance was performed in loans and grants. An assistance of 2,232,982 dollars was provided for Turkey, until November of 1951, as 1,143,084 dollars in grants and 1,089,898 dollars in loans (TRPMA, 30.1.0.0.125.801.5).

\section{Circulation Rights}

Circulation rights of 1948-1950 years are illustrated below (TRPMA, 30.1.0.0.80.507.5).

Table 5. Expense Local and the Sum Used by the Counterpart Monies Account of $95 \%$

A. Public sector

\begin{tabular}{|l|l|}
\hline Highways & $35,677,000$ \\
İskenderun-Erzurum road & $1,320,000$ \\
\hline Ziraat Bank & $15,339,000$ \\
\hline Technical assistance & $1,310,000$ \\
\hline Etibank & $42,352,000$ \\
\hline
\end{tabular}


(Table 5 continued)

\begin{tabular}{|l|l|}
\hline Highways & $35,677,000$ \\
İskenderun-Erzurum road & $1,320,000$ \\
\hline General Directorate of Statistics & $1,000,000$ \\
\hline Tuzla road & 403,000 \\
\hline Migrants & $30,000,00$ \\
\hline Mechanical and chemical industry corporation & $5,500,000$ \\
\hline Sum & $132,901,00$ \\
\hline
\end{tabular}

B. Private sector

\begin{tabular}{|l|l|}
\hline Cement industry & $7,063,000$ \\
Daricaand Zeytinburnu factory & $5,600,000$ \\
İzmir cement & 784,000 \\
\hline Kartal factory & 462,000 \\
\hline İzmir Gin and oil seeds factory & 612,000 \\
\hline İstanbul cold store and ice factory & $1,812,000$ \\
\hline Piramit factory & $1,534,000$ \\
\hline İbrahim Ethem Ulugay chemical house & $10,000,000$ \\
\hline Industrial Development Bank & $27,886,000$ \\
\hline Sum & $160,767,000$ \\
\hline Sum total & \\
\hline
\end{tabular}

Note: Source: TRPMA, 30.1.0.0.80.507.5.

Associations Allocated to Ministry of 1949-1950 years through Marshall Plan. The Agriculture: 1948-1950

$16,134,000$ dollars of this amount were allocated to

The $22,148,000$ dollars $(44.5 \%$ of the general agriculture in total, which created $13.8 \%$ of the general assistance) were allocated to Ministry of Agriculture that 49.7 million dollars were the total amount of assistance provided for Turkey in 1948-1949 years through Marshall Plan. The 117 million dollars were allocated to Turkey, as direct at 59 million dollars and circulation right from Europe at 58 million dollars, in assistance. The 14,626,000 dollars were direct assistance from America and the remaining 1,508,000 dollars were circulations rights from Europe. Until 1950, $38,282,000$ dollars were allocated to agriculture as direct assistance at 36,774,000 dollars and circulation rights at 1,508,000 dollars (TRPMA, 30.1.0.0.80.507.5).

Table 6. Circulation Rights Allocated to Turkey in the Period of 1948-1949 (000 £)

\begin{tabular}{lll}
\hline & Allocated & Used \\
\hline Belgium & 2,000 & 2,000 \\
Italy & 5,000 & 2,515 \\
Holland & 800 & 586 \\
England & 8,000 & 8,000 \\
Sweden & 1,000 & 1,000 \\
Sum & 16,800 & 14,101 \\
\hline
\end{tabular}

Note: 2,699,000 £ unused were added in the collection of 1949-1950 years. 
Table 7. Circulation Rights Allocated by Turkey in the Period of 1948-1949 (000 £)

\begin{tabular}{lll}
\hline & Allocated & Used \\
\hline Germany & 13,500 & 6,778 \\
Denmark & 1,500 & 700 \\
Greece & 12,300 & 12,300 \\
Norway & 500 & 84 \\
Sum & 27,800 & 19,862 \\
\hline Note: Unused balance of 800,000 dollars of the circulation right allocated to Denmark by Turkey and of 416,000 dollars the \\
circulation right allocated to Turkey by Norway was cancelled and balance of Germany of 6,722,000 dollars was transferred to the \\
period of 1949-1950.
\end{tabular}

Table 8. Circulation Rights Allocated to Turkey in the Period of 1949-1950 (000 E)

\begin{tabular}{lll}
\hline & Allocated & Used \\
\hline Germany & 14,722 & 14,722 \\
Austria & 1,000 & 1,000 \\
Belgium & 5,123 & 5,123 \\
Denmark & 2,850 & 2,850 \\
France & 7,000 & 7,000 \\
Italy & $6,248^{*}$ & 6,248 \\
Holland & $5,926^{* *}$ & 5,926 \\
Norway & 468 & 468 \\
England & 28,684 & 28,684 \\
Sweden & 2,200 & 2,200 \\
Sum & $74,221^{* * *}$ & 74,221 \\
\hline Notes: ${ }^{*} 2,485,000 £$ were inherited from the period of $1948-1949 .{ }^{* *} 214,000 £$ were inherited from the period of $1948-1949$.
\end{tabular}

Table 9. Circulation Rights Allocated by Turkey in the Period of 1949-1950 (000£)

\begin{tabular}{lll}
\hline & Allocated & Used \\
\hline Germany & $6,722^{*}$ & 6,722 \\
Greece & 8,000 & 7,503 \\
Sum & 14,722 & 14,225 \\
\hline
\end{tabular}

Note: ${ }^{*}$ It was inherited from the period of 1948-1949.

The 6,576 tractors, 9,079 tractor ploughs, 3,456 disk harrow, 1,262 harvesters, 1,439 cereals seeders, 2,732 cotton seed machines, 2,516 one-way ploughs, and 104 pick-up vans of the agricultural implements were ordered. These implements and machines brought within the scope of Marshall Plan were imported and sold through companies. Import and sale processes were carried out in accordance with provisions of directive no. 10.138. While 2,338 tractors in total were available in Turkey in 1948, this number reached to 5,781 until July 27,1950 by adding
3,443 tractors sold within the scope of Marshall Plan. Tractors that came out of the Marshall Plan since 1948 are not involved in this number. It does not include tractors importer companies which are not sold still or of which sale details are not submitted to the Ministry within the scope of Marshall Plan, as shown in Appendix 6 (TRPMA, 30.1.0.0.80.507.5).

Purchase, import, and local sale of the agricultural implements, machines, and materials; and agrochemicals and instruments, chemical fertilizers to be imported to Turkey by assistance loan of Marshall 
are specified by a protocol (TRPMA, 30.1.0.0.80.506.8).

According to this, tractors, agricultural implements and machines imported to Turkey through Marshall Plan were assigned to the provinces at first ${ }^{15}$ and these assignments were distributed to farmers by means of Provincial Distribution Agencies. A farmer having enough land consulted to the province and submitted a declaration composing of the size of process, type of the device to purchase, etc. and then received a document of supply. These documents could not exceed the amount assigned to that province. Farmer having the document purchases the required equipments anytime in that year, as paying $37.5 \%$ in advance and the remaining part in four installments. As this assignment system was found risky, it was abandoned since August 1949 and sales were released completely. According to the new application, being a farmer and receiving a farmer certificate is enough to have tractors and other machines. The ministry gave purchasing processes up completely. Farmer can purchase the device he wanted in advance or by installments (TRPMA, 30.1.0.0.80.507.5).

Sales on credit are performed directly by the company or via Ziraat Bank. Maximum installment term is specified as six years. The first installment is $20 \%$ in advance for the sale. Every year, installments are assigned in perception or marketing season of the main product in that region and $2.5 \%$ interest is also added at the end of period. Even though rate of profit by $20 \%$ over (the purchase + foreign carriage) price of the goods was assigned to the companies in sale, this limit has been increased to $25 \%$ for the last time. This added rate of $5 \%$ would be spent to carry out works concerning maintenance, service, and farmer teaching in order to increase performance of the implements and machines. Sale price of the spare parts was specified based on spare part list price of the manufacturer factor. Sale price of the spare parts imported from America was specified as 4.5 times more than list price and 4.3 times more than Canada.
For example, a spare part of which price is one dollar in the USA will be sold in 4.50 cents and of Canada will be in 4.30 cents across the Turkey; this rate is calculated as 4.8 only for John Deere factory. Rate of profit is $25 \%$ for the tractor tires (TRPMA, $30.1 .0 .0 .80 .507 .5)$. It is seen here that sales strategy commonly used nowadays is tried to be carried out. The product was purchased by an advantage to pay under proper conditions and then an effort to gain excessive profit came into prominence by applying high price on spare parts.

Machinist courses were opened to train farmers on use, maintenance, and repair concerning tractors and other agricultural implements and machines imported by Marshall Plan. At first, it was started in different regions of the country during spring of 1949 and 1,200 personnel were trained last year by means of the courses in these 12 places that each one lasted six months. Sugar factories made a contribution by training 450 machinists. Number of the courses increased up to 20 in 1950 and it was intended to train 2,000 machinists. As for course period, it was reduced from six months to five months. Cooperation was established between the import suppliers in order to increase performance of implements and machines, and these suppliers established mobile and fixed shops. It was paid attention to spare parts in terms of performance increase and spare parts were imported up to $10 \%$ of agricultural implements and machines prices imported last year. This rate was increased to $20 \%$ in 1950 . Spare parts of 2,213,000 dollars were imported and spare parts of 2,000,000 dollars were ordered. Companies were recommended to sell them to farmers as a team in order to maintain performance of agricultural devices. Sugar factories enable to sell the tractors and other devices used accompanied with them to groups of 3-6 farmers (TRPMA, 30.1.0.0.80.507.5).

Ministry of Agriculture used the technical assistance in three ways. The 28 certified agricultural engineers and two academicians of Agricultural 
Faculty were sent to America and it was decided to send also five veterinarians. In addition, it was adopted to send several personnel to America who would specialize in hybrid zea mays growing, cotton field, forestry field, etc. Personnel of different fields were sent to the USA in order to use opportunities of technical assistance within the scope of Marshall Plan and increase their good manners and knowledge and specialists were requested from the USA. It was possible to import pedigree seed and animal for breeding (TRPMA, 30.1.0.0.80.507.5).

Seven American specialists came to Turkey on March 28 of 1950 in order to use technical assistance and completed their studies in Çukurova and Southeast, Marmara, Ege and Trakya regions. These investigations would prepare a new and modern agricultural program for Turkey after being completed. On May 18 of 1950, an expert of hybrid zea mays came to Turkey and carried out studies in order to test different hybrid zea mays seeds up to $800 \mathrm{~kg}$ which were imported from America. It was started to get ready to send 50 agriculturists, 15 veterinarians, and 15 foresters to America (TRPMA, 30.1.0.0.80.507.5).

It is seen that assistances for four years under ordinary conditions were enlarged for Turkey ${ }^{16}$. Although Marshall Assistances were cut in many European countries from the first six months of 1950s, they were continued in certain European countries, notably Turkey, in direction of the requirements from the USA economy and its allies (Avşaroğlu 2008).

Economic assistance was approximately 70 million dollars that were supplied by America to Turkey in 1952. The 10\%-15\% were in loan and the remaining were in grant as being an assistance to be supplied as economic assistance at 43 millions and military assistance at 25 millions. Erkin explains the attempt for increasing assistances in grants. For example, assistance of 300 million dollars projected to provide for France was increased up to 252 million dollars. Erkin considered connections as inconclusive and according to his impressions, while American authorities approved to provide credit for Turkey, certain European governments at European Payments Union aimed to take over the biggest part of assistance provided for Turkey through private sources (Erkin 1999: 383-386).

In addition, he encountered a response that they hesitated to turn this fund received as loan into grant by American authorities since it could be an example for other countries. And Erkin responded in this regard as the following, and it caused a positive effect:

We received assistances by Marshall Plan less than all other countries and these countries received in grants but the big part of this assistance was in debt for us. Debt ratio was $37 \%$ that we all had. This ratio was $8 \%$ for France, $11 \%$ for England, and $15 \%$ for Holland. Then, different treatment was completely against us until today. Now we want a treatment equal to others. (Erkin 1999: 431)

This higher amount compared to the other countries is the reflection of the practicing double standard for Turkey. Grant credits opened to the full extent for European countries would allow economy of these countries to improve much more rapidly and they could head towards production and marketing while Turkey was dealing with debts and interest in long term.

According to American International Bank, it would not be realistic to provide convenience for Turkey in terms of paying the debts since it did not use a big part of credits opened within the scope of Marshall Plan. Erkin, in replying this criticism, stated that government went after construction activities to be executed for years instead of orders such like purchasing tractors, etc., and it would take a long time and that the unused credits would have been used in this way. In the period of 1952-1953, Turkey was supplied by additional assistance of nine million dollars as six million dollars in purchasing within dollar area and three million dollars in private source by Marshall Plan Administration, recently named as 
Mutual Assistance Administration (Erkin 1999: 431, 434).

\section{EFFECTS OF MARSHALL PLAN}

Marshall Plan is a structuring process having an obvious effect on the world. It resulted in an economic commitment to the USA for not only Turkey but also European countries. When considered in long term, even though these countries could not avoid a commitment to the USA, they also found an opportunity to revive an economy of Europe that was collapsed in general. Besides, even though the regulation saved Europe as it was European centered, it caused development of communist movements in the Far East countries (Şahin 2014: 166-167). Commercial relation between East and West was minimized as it was forbidden to send strategic materials to East countries (Ünsal 2011).

America provided the participant countries with the assistance of 13 billon dollars ${ }^{17}$ within the scope of Marshall Plan. As a result of assistances, European investments of American companies that increased by $1.5 \%$ times in the period of $1929-1940$ showed an increase of $38 \%$ in mining sector, $58 \%$ in industrial products, and $143 \%$ in petrol products between 1947 and 1950. This increase continued in the following years; while investments of American companies increased by $320 \%$ in Latin America and by $556 \%$ in Asia in the period of 1950-1970, rate of increase was $1400 \%$ in all their investments in Europe and number of American Bank opened a branch in Europe increased from six to 72 in this period (Çağr1 1996).

This structure is product of the effort to rebuild both European economy that took a major blow after World War II and the capital left Europe before the war. The system, intended to be practiced through certain statements such like "reconstruction for the world", allowed a money transfer of 51 billion dollars in total by means of American loans and grants between 1946 and 1954. And this monetary structure was controlled by the World Bank (IBRD) and International Monetary Fund (IMF) constituted. Countries involved in the system headed towards being a commercial market and the countries were encouraged to purchase goods by debiting through the loans opened by relatively rich countries (Avşaroğlu 2008).

Movement was arranged for money capital through IMF established within the scope of Bretton Woods Agreement, for productive capital through IBRD (International Bank for Reconstruction and Development) and for commodity capital through GATT (General Agreement on Tariffs and Trade). After these arrangements, Marshall Plan was brought forward because surplus production in the USA would be utilized through the outflow of capital and in order to rebuild the whole of capitalist affairs in Europe where the process of capital accumulation was therefore stopped considerably after the war.

Marshall Plan appeared as a factor that forms a basis of the dynamic of internationalization of the productive capital. This mission undertaken required plan to be built so as to accelerate process of capital accumulation for Western European countries - in a way to create a demand in investment goods produced in the USA - and also create a safe zone for the direct investments of the USA capital by means of deepening (again) the whole of capitalist affairs in these countries. In other words, Marshall Plan was built with a purpose to accelerate the process of capital accumulation in Western European countries as well as it created opportunities to utilize capital of the USA... Capital issued through Marshall Plan opened the way to export of goods. (Tören 2006: 210-211)

Mining industry was one of the most important areas created by Marshall Plan for the USA and European companies. Process to accumulate capitals of the USA and Europe would be supported through the machines and turnover imported and raw material required by the countries in question would be thus supplied (Avşaroğlu 2008).

European continental economy showed a development unprecedented throughout history 
through Marshall Plan and production increased by 35\% between 1948 and 1952. Famine and poverty accompanied by the war disappeared and standard of life improved visibly over 30 years following the assistances. European peoples stayed quiet on this hegemonic structure with the big poverty during and after the war and European communist parties gained a great sympathy over the years of falling from grace through Marshall Plan. Idea of European Union ${ }^{18}$ was founded through Marshall Plan and the USA supported the idea of European Union as it supported free trade. "Marshall Plan, in fact, means also globalization today. Globalization appears as a phenomenon emerged from the capitalism within the period from the execution date of this plan until today" (Avşaroğlu 2008).

\section{Its Adverse Effects on Turkey}

When we consider Marshall Plan and implementation process, it appears that it resulted in important impacts on Turkish economic, social, and political history, and it was required to evaluate advantages and disadvantages of these impacts together.

According to Çetin Yetkin, foreign assistance is a policy instrument. Assistance would stop if requests of the country providing the assistance had not been met. It is very undesirable for the countries addicted to the assistance. President of the USA, John F. Kennedy declared at Economy Club in New York in December 1962: "Foreign assistance is a method by which United States affects and controls on the world" (Yetkin 2002: 360).

Foreign policy of the USA after World War II had military, economic, social, and cultural impacts on Turkey and certain issues came up such like transition to a multi-party system, "Closing Village Institutes that was an education model pertaining to Turkey"19, struggle with communism, etc. (Aslan 2014: 88). England and the USA opened the way for Turkey to enter Western alliance as they decided in a short time that requests from the Soviets posed a severe thread on interests of the USA and therefore they should be retorted (Güler 2009: 210).

Commercial capital, reaching a certain accumulation during the war, was disturbed as it was intended to leave Turkey out Marshall Assistance at the beginning, and this condition was held over power of that period. Contrary to the common view, involvement of Turkey into that plan was not a unilateral process demonstrated by the USA, it was a process made actual within the scope of internal and external factors formed by the direction of Turkish capital. And Republican People's Party (CHP) was the initiator, not Democratic Party (DP) (Tören 2006: 216).

The USA that provides assistance but controls the use of sources according to the Agreement for Economic Cooperation provided assistance of 351 million and 700 thousand dollars for Turkey within the scope of Marshall Plan between 1948 and 1952 (Yücel 2001: 67). In addition, 140.2 million dollars were granted within four-year period. Turkey received not only grant but also loan from the USA through Marshall Plan. Approximately one billion and 207 million and 434 thousand dollars were allocated until the end of 1959 and only $11.8 \%$ of this allocation were grant. An allocation of 666 million and 800 billion dollars is in question between 1960 and 1962 . Lower amounts of grant and higher amounts of loan brought about difficulties in repayments over the time (Şahin 2014: 164).

Substructure was prepared that was required structural transformation demonstrated in the period starting with American foreign assistances in Turkey as in Europe. Public entrepreneurship was reduced and the private sector was involved further in the economy, and an aim of industrialization was demonstrated which was based on processing agricultural, forest, animal breeding, construction materials, and light metals instead of the heavy industry (Avşaroğlu 2008).

Assistances were utilized mostly in importation financing. Foreign trade deficit and cost of living 
appearing in time would constitute the agenda of Turkey for a long time (Topal 2013). The plan could not accelerate development in Turkey just like started in other European countries, due to either policies imposed by the plan or short-term wrong policies of the plan and it convicted Turkey to spiral of foreign loan, foreign assistance, and foreign capital (Bülbül 2006: 136). Besides, a success could not be reached in agriculture except that industrialization, and Turkey was turned into an agricultural importer after 1954 (Tören 2006: 218).

In addition to this, deficit became bigger between import and export.

Turkey grew rapidly through the plan; however, this condition stimulated the increase in export. The sum spent for import in Turkey exceeded the sum of export and external deficit increased in economy. Turkey that was deprived of economic policies to prevent this case couldn't pay off the debts and had to take loan again. Devaluation practice of 1946 couldn't meet the foreign trade deficit. Any precaution was not taken even after this practice. Under these circumstances, economic crisis started to reappear in Turkey as from 1956. The USA that took the Turkish economy in hand stipulated to develop a system of economic stability and constituted an institution in the form of Public Debts in order to pay the debts. Turkey thus became foreign-dependent again. On the other hand, the USA started to intervene directly in internal affairs of Turkey. (Şahin 2014: 164)

Turkey had to allocate a large part of the investments to military expenditures due to the internal and external dynamics of that period although it utilized in the most efficient way these assistances received (Topal 2013). Some circles in the USA spoke highly of this case and William Konowland, the California Senator, stated that Turkey participated completely in the common action by making big progresses in armament and preparation for defence. While America allocated $30 \%$ of the budget to defence expenditures, Turkey allocated $35 \%-40 \%$ of its budget. It was indicated that it was a different problem that certain allies remained in a little rate such like 5\% (Erkin 1992: 183).

The USA assistances and trainings starting with Truman Doctrine began to change not only material infrastructure of Turkish Armed Forces but also human infrastructure. American field manuals, series of FM (Field Manuel) composing of tactics and concepts prepared in the main theme of enmity against the Soviet, entered the inventory of Turkish Armed Forces. However, an understanding that took transfer of knowledge to the forefront instead of producing knowledge and introduced old technologies as innovations started to standardize ideas and perspectives of Turkish Armed Forces personnel, and military intellectual structure was affected adversely in that period (Kalyon 2010).

According to Doğan Avcioğlu, modernization of Turkish army was transferred to America through Truman Doctrine. Hasan Saka signed the agreement of assistance which did not permit use of arms supplied in summer of 1947 for the wrong purposes. Turkish generals going to Washington were told about communism thread. In that, Chief of Defence Staff, Salih Omurtak had to explain in the press conference conducted in Washington that communism thread was not present in Turkey (Avcıoğlu 1978: 1607).

Military and economic external dependence was thus founded by Truman Doctrine, and rise in those who adopted American style prevented development of Turkish left and social democratic action (Kalyon 2010). Significant problems appeared in the affairs as the USA regarded Turkey as little partner in this alliance and only a station against the Soviet Union, and serious tensions were experienced between two countries due to Cyprus problem especially in 1960's (Gürbüz 2010).

For Cem Eroğul, foreign policy of which Democratic Party was in the forefront is the most obvious evidence for the comprador quality of the dominant classes for whom it conducted spokemanship. Imperialism wanted Turkey to be exporter of raw material and a dependent country open 
to investments of foreign capital. Actions of Democratic Party were in that direction. The most important attempts in economics were in agriculture and principal structure fields and it is seen that big successes were achieved compared to the previous period. However, parasitic classes were created due to the policies of ${ }^{20}$ private entrepreneur and foreign capital (Eroğul 2014: 264).

\section{Positive Effects on Turkey}

Purpose of the assistances allocated by the USA to Turkey after World War II was not to develop heavy industry but it was to design an industrial model based on agriculture. Within the scope of this purpose, a significant amount of source was allocated to develop infrastructure requirements of agricultural sector, the part of 38.282 million dollars of 184.5 million dollars was utilized to develop agriculture between 1948 and 1952 (Özer 2014: 437).

Low interest loans, provided for mining machines and equipments within the Marshall Plan, enabled to make production also in the mine sites especially belonging to small investors. Sites that were blocked in accordance with Article 7 of the Law no. 2804 were opened to mine production in 1950 and then private sector was referred to this field; 619 exploration licenses were issued to the applicant investors and also 19 of them received business licenses. Prospecting activities were conducted by Mineral Research and Exploration Institute in Kozlu, Çatalağzı, Kandilli, and Çamlı regions by means of an American company of drilling in terms of minerals needed by European countries notably coal, etc. Lignite drawing activities were conducted in several regions such like Soma, Tunçbilek, Değirmisaz, Ağaçl1, as well as Zonguldak Coal Field (Avşaroğlu 2008).

It was projected to increase production in washed lignite up to 975,000 tons in $1950,1,206,000$ tons in 1951 , and $1,680,000$ in 1952 that was 788,606 tons in 1949 with the private sector, and Eximbank was applied in addition to funds appealed within the scope of Marshall Plan. Direct assistance of 48,579,675 dollars was allocated to Etibank from the beginning to June 30, 1957 in the regions where iron, chrome, lead, gold, silver, and antimony minerals were extracted. Between the years of 1949-1953, while the sum of indirect assistances utilized in import of construction materials and machines from the European countries reached up to $25,589,876$ dollars, Ereğli Coal Enterprise received the biggest share of indirect assistances and coal production conducted by Etibank was transferred by it to Turkish Coal Enterprises after 1957-1958 (Avşaroğlu 2008).

According to Serkan Şahin, the only advantage of Marshall Plan was probably the system of counterpart monies. System of counterpart monies was composed of the Turkish liras gained by sale of materials supplied by the assistances to the public. Although the monies collected ${ }^{21}$ were introduced as having the characteristics of internal financing of economic development and as quite useful, monies were kept into an account of Central Bank. This system of which use depended on the content of the USA resulted in the intervention of the USA in internal affairs of the country (Şahin 2014: 166).

Moreover, it is stated that Turkish-American convergence started by Marshall Plan made important contributions to employee rights in Turkey having fragilities in struggle with communism and that a considerable assistance was provided in terms of development of organizational abilities and collective-labor bargaining. Right to strike, by the way, came until 1960s as an unsolved problem (Öner 2006: 93).

\section{CONCLUSIONS}

Truman Doctrine and Marshall Plan of the USA accelerated the political developments appearing at the end of World War II and were demonstrated primarily to limit sphere of influence of the Soviet influence in Europe, and Turkey perceived immediately the need 
to head towards Western democracies again due to the Soviet influence and wanted to be within this structure. The process to involve in Marshall Plan started in 1947-1948 when Republican People's Party (CHP) was in power, after necessary agreements were made during the power of that party, it was continued also during the period of Democratic Party that took over the power by elections in 1950 .

While the USA adopted to introduce "Marshall" all over the world and Turkey as a "movement of assistance"; "Marshall Assistance" or "Assistance Plan" terms were seen even though "Marshall Plan" term was used mostly in formal correspondences in Turkey.

Turkey was a member of Organization for European Economic Cooperation just like other countries in order to utilize Marshall Plan and it was included in the process by making the required changes in several stages of the state after the Agreement for Economic Cooperation was made with the USA, and the relevant legal regulations were made in order to elicit the deficiencies emerging over the time. Besides, it was mainly criticized by bureaucrats from the USA and it was complained about disconnection, unwieldiness, failure to fulfill the required works, etc. between the institutions of the state. As Turkey was approached by a different attitude compared to other countries concerning providing credit facilitates, as seen in the statements of Feridun Cemal Erkin, the USA Ambassador of that period, they complained about generosity for other European countries, for example France, was not presented for Turkey in the point of providing non-repayable grants.

While the USA intended to direct Turkey towards developments especially in agriculture, mining, and tourism sectors within the scope of Marshall Plan, as the industry remained underdeveloped ${ }^{22}$, it was not intended to make investment in that field. Besides, transfer of a significant part of credits to military field was received favorably by the USA.

It was understood that Turkish politicians and decision-makers intended to go beyond the line drawn by the USA and tried to give primacy to infrastructure works toward the production even though developments causing the complaints of American experts from time to time could be attributed to the non-communication of the bureaucracy in Turkey. It does not seem correct to claim that Turkish directors were completely disorganized. In other words, the USA governments dictated an economic model that was drawn by it and did not exceed the lines. Role provided for Turkey was to create a buffer zone against the Soviet Union and even Iran, produce farm products needed by Europe, and process the minerals for the need of the USA. However, Turkish governments projected to direct the quotas allocated to them towards main infrastructure works, construction sector, and industry sector, just like today, and to use them in the locomotive sectors but it was not permitted.

Tractors and other devices required for the agriculture, entered the country in an amount of two or more times larger within two years, and created important developments in this sector. However, it should be noted that persons or companies without a certain amount of capital accumulation were less likely to utilize purchase-sale and other processes related to Marshall Plan even though it was criticized by some sections on the grounds that a comprador class was created in the country.

Even though a four-year period was specified for participant countries within Marshall Plan, duration was enlarged for some countries and Turkey. In Turkey, Marshall Plan (Assistance) has been discussed in several sections today, and governments of that period-especially Directors of Democratic Party and the Prime Minister Adnan Menderes by adopting a non-objective attitude in the process started with Republican People's Party (CHP)-were criticized on the grounds that Turkey was put under the domination of the USA by the left sections. We want to remind that devaluation ${ }^{23}$ practiced at the end 
of 10 years as from the beginning of execution of the plan and military coup of 1960 as a disgrace on Turkish democracy create question points in the minds.

It is obvious that an important convergence experienced in Turkish-American relations through Marshall Plan. We encounter cultural effects of this convergence as well as political and economic aspects. In that, Turkey's cultural tendency for Western headed towards the USA rather than European countries, and American effect (Çatalbaş and Koç 2016) appeared considerably in almost all branches of art especially at the Democratic Party period.

\section{APPENDIX}

Appendix 1. Speech of Truman for Ankara Radio

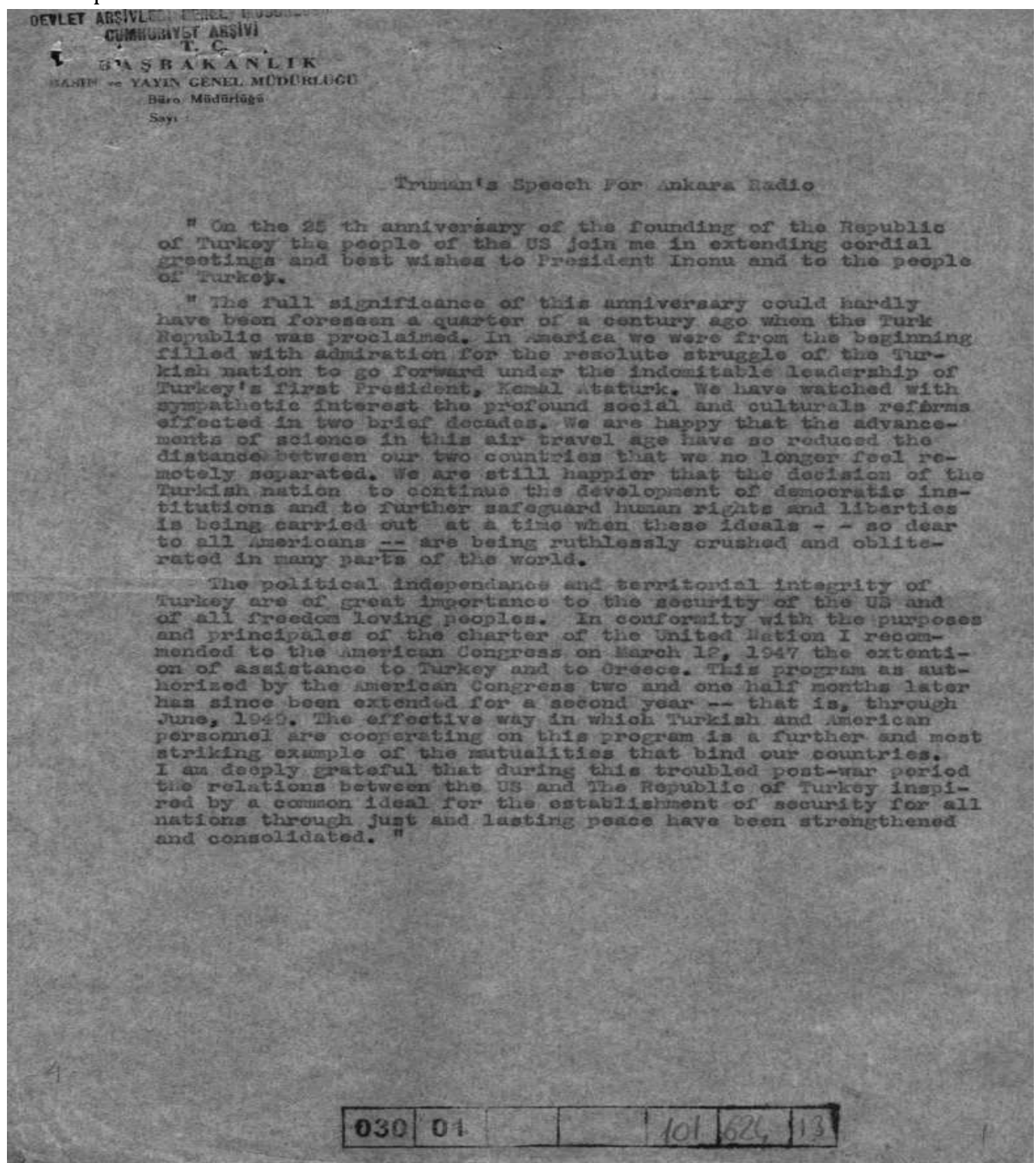

Note: Source: Turkish Republic Prime Ministry Archives, 30.1.0.0.101.624.13. 
Appendix 2. Telegraph of Kindness From General Alexander Marshall to Prime Minister Şükrü Saraçoğlu
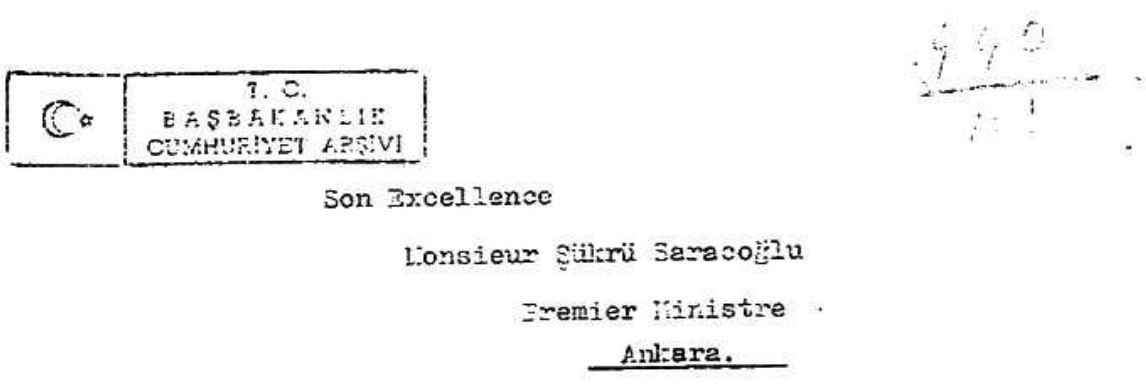

On behaif of the troops uncer ny jomand, I than: you for zour kino and encourejing message of concratulations.

żeld Larshai fle:anäer

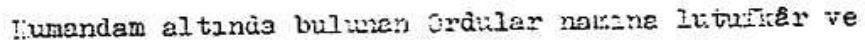

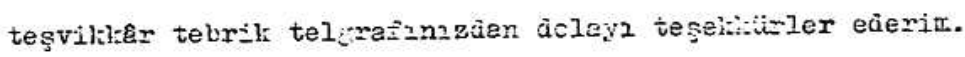

Ėeià :ar shą Alexanäre

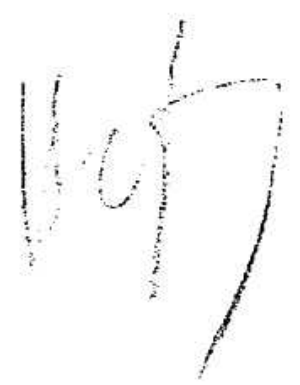

$-1-$

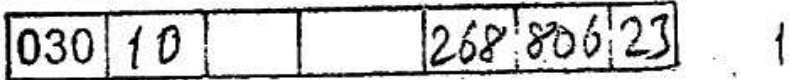

Note: Source: Turkish Republic Prime Ministry Archives, 30.10.0.0.268.806.23. 
Appendix 3. A Decree of Council of Ministers and President of Republic Ismet Inönü Concerning the Marshall Assistance

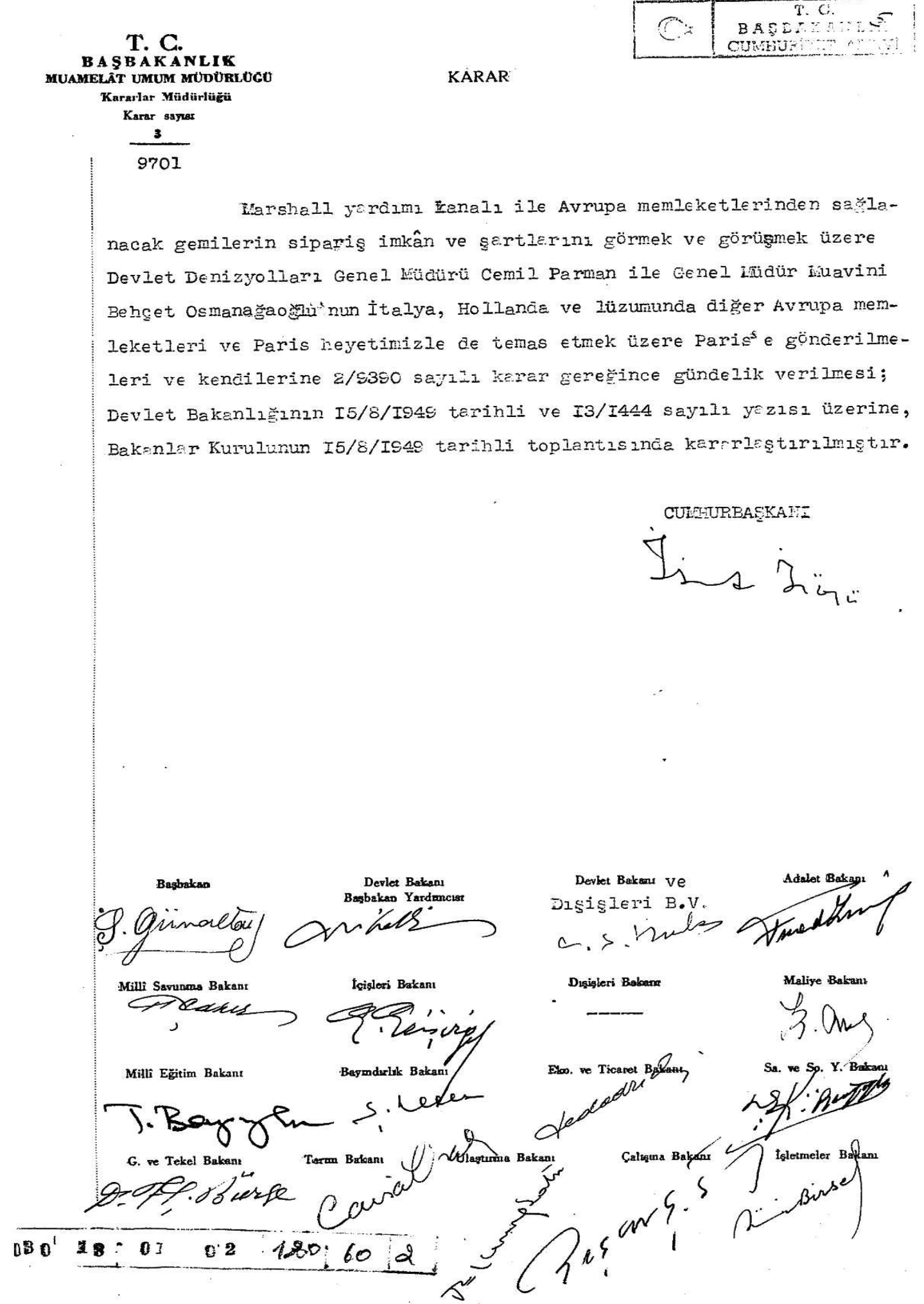

Note: Source: Turkish Republic Prime Ministry Archives, 30.18.1.2.120.60.2. 
Appendix 4. A Decree of Council of Ministers and President of Republic Celâl Bayar Concerning the Marshall Assistance

T. C.

B A SBAKANLIK

MUAMELAT UMUM MÜDÜRLÜGÚ

Kararlar Müdürlï̌̆̈̈

$$
\text { Kaner saynss }
$$$$
3
$$

11375

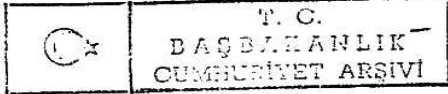

KARAR

I5/I2/IO49 terihli ve 3/I0256 saylll karere ektir. Birleşik Amerika İkisedî İ̧ỉirliği İaresi ve Avrupe Iktisadî Işbirliöi Teşkilêtiyle yepllan temeslarđa harsinal yardımı şumulüne Eiren mevzulfraan (20z) talepnamelerini, tekrik yerdim telepneme ve müseadele rini Türkiye adına inzelawés iģin Başbakenlık b.illetleraresı Ikstisadi İ̧birliği Teşkilâtı Birinci Daire Beşkeni Bülent yezıç'ya de yetki veriluesi; Bekenler Kurulunun Ia/6/I950 tarihli toplantısınde karerlaştırılmıştır.

CUL.HURBA ŞKANTI

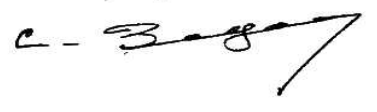

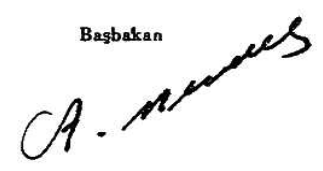

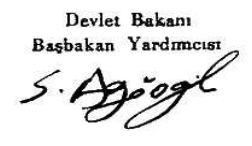

Millî Ssvunms Bakanı Refit s. inve

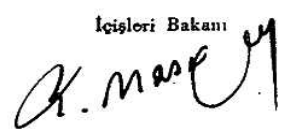
Milli Eğitim Bakanı

\section{Bayındırluk Bakan}
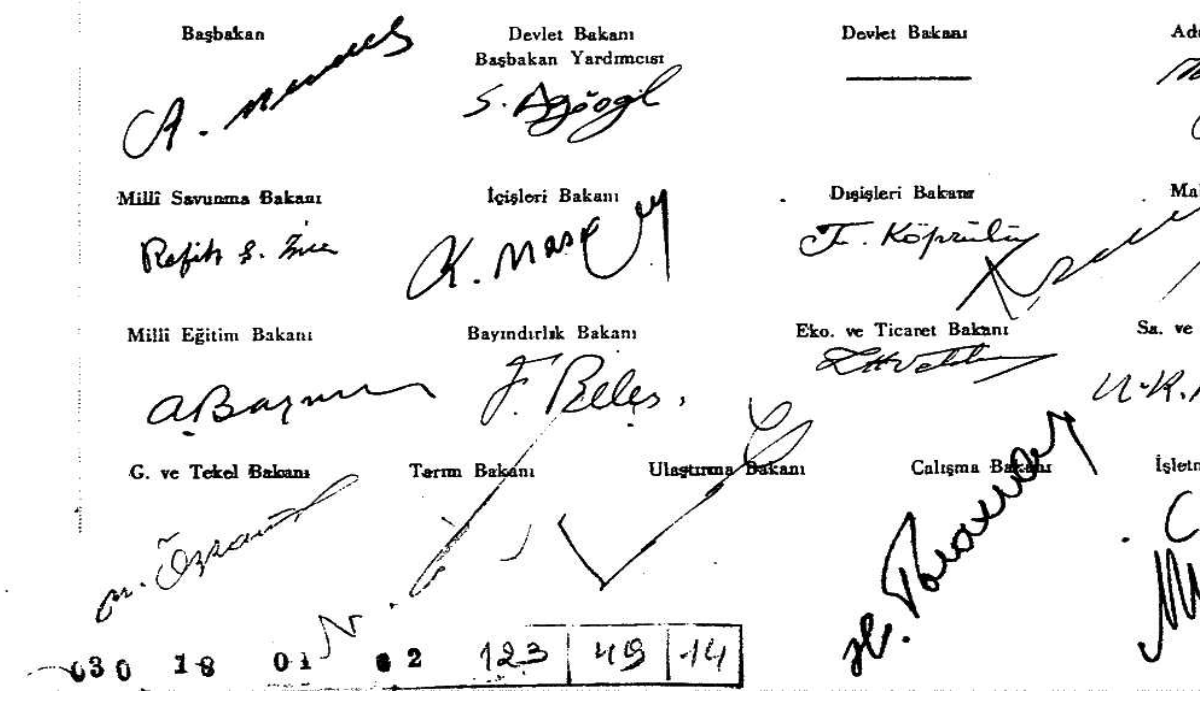

Adalet Bakant, Adalet Bakant,

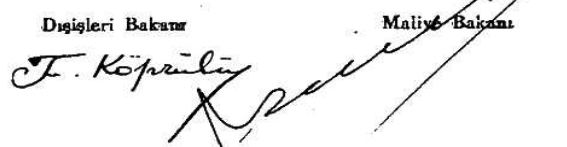
Eko. ve Ticanet Bakant Sa. ve So. Y. Badaant Quveth

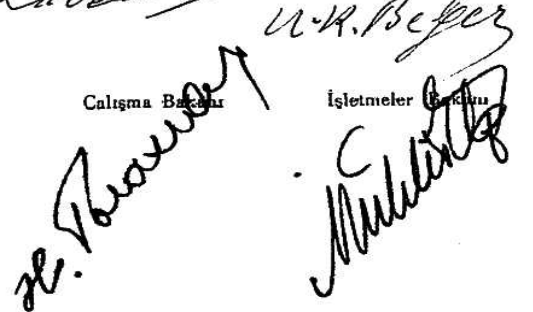

Note: Source: Turkish Republic Prime Ministry Archives, 30.18.1.2.123.49.14. 
Appendix 5. A Greeting Telegraph From Prime Minister Adnan Menderes to the USA Regarding 10th Anniversary of Truman Doctrine

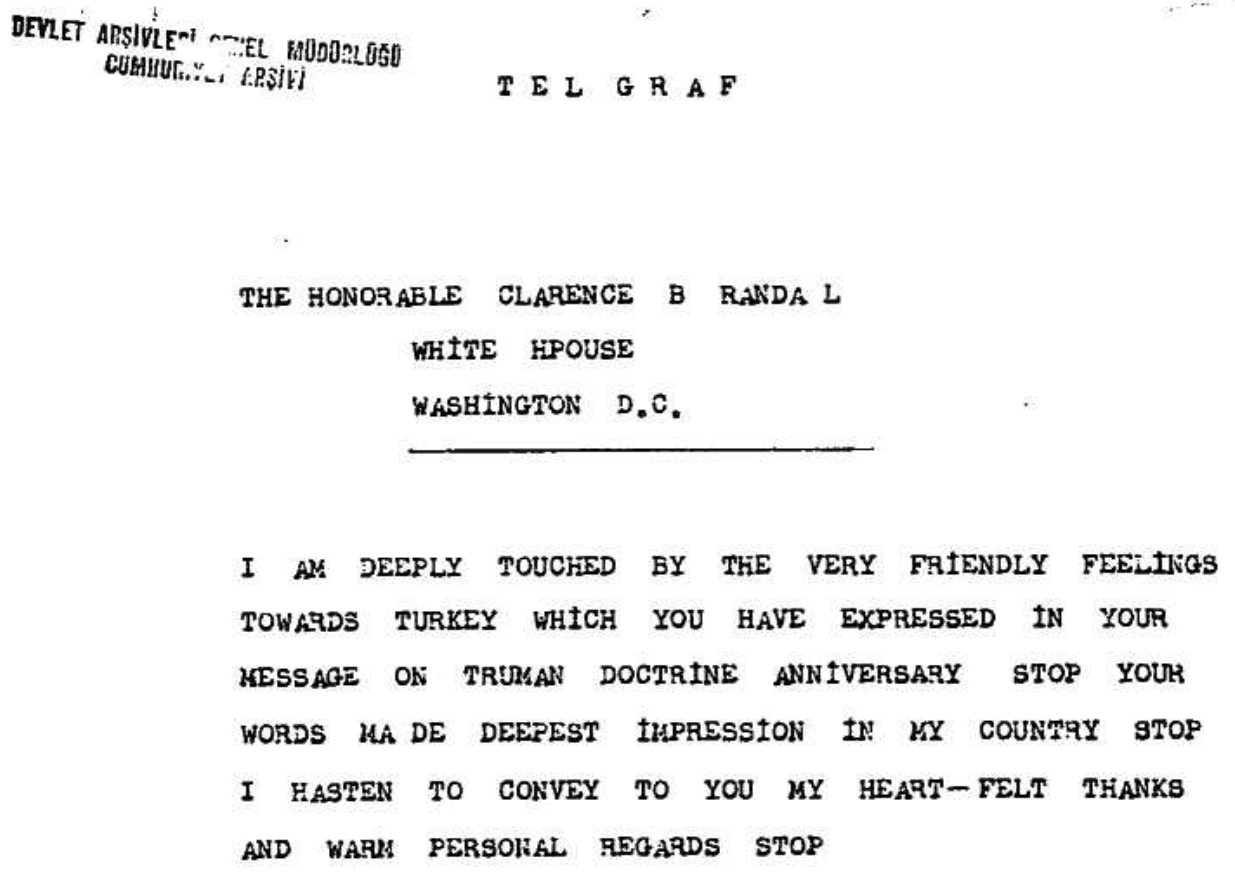

ADNAN MENDE:ES

- ànan Menderes

Bą̧veis1l

AEl1 E1:1a1r.

26 uart 1957

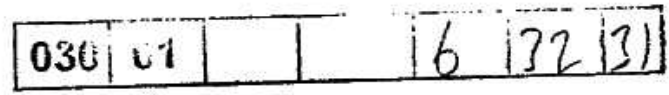


Appendix 6. Several Allocations to Turkey Through Marshall Plan

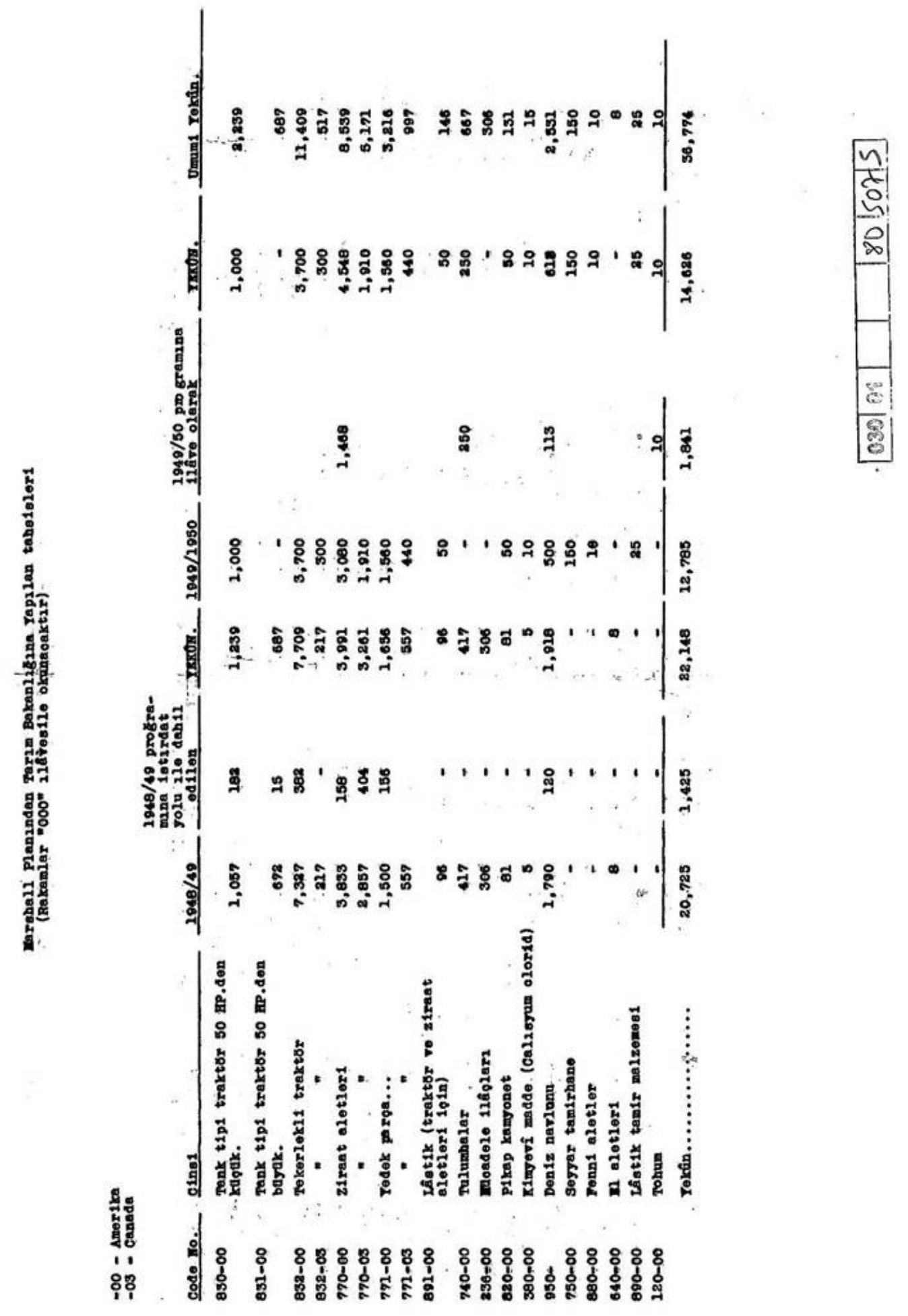


Eor

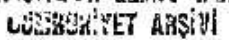

$$
\text { L4 ate 6: } 4
$$

Memieketimazde firmaler tarafindan kurulmug ve kurulacak jabet ve seyyar terirhanelerin yerlerinl Bboteris o etrez

\begin{tabular}{|c|c|c|c|c|}
\hline \multirow{3}{*}{$\frac{\text { Dimatal }}{2 . D a n a t 20}$} & \multicolumn{2}{|c|}{ Kurulmug } & \multicolumn{2}{|c|}{ Kurulacok } \\
\hline & Bablt & Sexvar & Sabst & Sorryax \\
\hline & $\begin{array}{l}2 \text { Konsa } \\
1 \text { Adena }\end{array}$ & 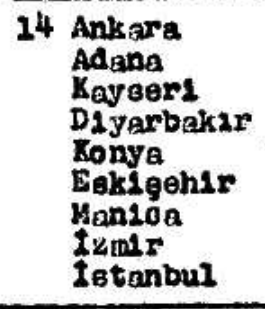 & $\begin{array}{l}2 \text { Ankaxa } \\
\text { 1 Ddyarbaksy } \\
1 \text { Man18a } \\
1 \text { Adana }\end{array}$ & I Trakya \\
\hline Gukurovs & $\begin{array}{l}\text { I Istanbul } \\
\text { I Adana }\end{array}$ & & $\begin{array}{l}1 \text { Irmax } \\
1 \text { xonya }\end{array}$ & $\begin{array}{l}1 \\
\text { Idona } \\
\text { Konya }\end{array}$ \\
\hline Xog & $\begin{array}{l}1 \text { Ankara } \\
1 \text { Irmir } \\
2 \text { Adana } \\
2 \text { Eonya } \\
1 \text { Antalya }\end{array}$ & $\begin{array}{l}2 \text { Eek1gehix } \\
1 \text { Ankara } \\
2 \text { Antal ya } \\
\text { Aakna } \\
\text { Gaslanter }\end{array}$ & 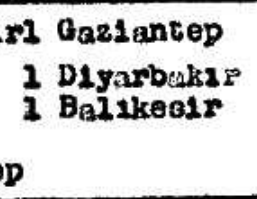 & $\begin{array}{l}1 \text { Unsa } \\
1 \text { antalya }\end{array}$ \\
\hline Turk Inter & & & 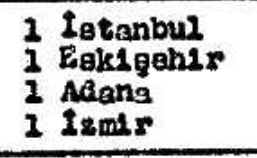 & $\begin{array}{l}1 \text { Fokdgehlr } \\
\text { I Adana }\end{array}$ \\
\hline Yaksndog̈u & I Istanbul & $\begin{array}{l}2 \text { Trakya } \\
\text { I Xoosell }\end{array}$ & $\begin{array}{l}1 \text { Adena } \\
\text { I Trakya } \\
2 \text { Izmir } \\
1 \text { Antelya } \\
\end{array}$ & $\begin{array}{l}\text { I Xonya } \\
\text { I Buroa }\end{array}$ \\
\hline Neptun & & & I Latanbul & $\begin{array}{l}2 \text { Trakya } \\
1 \text { Eokd gohs } \\
1 \text { Izmir }\end{array}$ \\
\hline Matas & 2 Iatanbul & & & I Adana \\
\hline Yekuin;: & 31 & 28 & 18 & 23 \\
\hline
\end{tabular}


6.

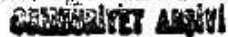

27/7/1950 glinline kadar Türkiye'de mevcut traktorlerin . vilâyetler 1tiberile dağilışı

111

1948 de mevcut $27 / 7 / 1950$

gưnüne kadar Yekûn

Narshall'dan

Afyon

$A$ STI

Amesya

Ankara

Antalya

Aydin

Balikesir

Bilecik

B1ng61

B1tils

Bolu

Burdur

Bursa

Ganakkale

Cank1 ri

corun

Corum

Denlzl1

Diyarbakax

Bdil rne

Eláz2

Erzincan

Brzurum

Eskişeh1r

Gazlantep

G1resun

Gtmuş̧hane

Ha tay

I çel

I sparta

Istanbur

$1 \operatorname{an} 1 r$

Kars

Kastamonu

Kayser1

Karklare11

Kırşeh1r

Kocael1

Konye

Kutahya

Malatya

Hanisa

Naras

Marain

Muǧla

kus

satzlan

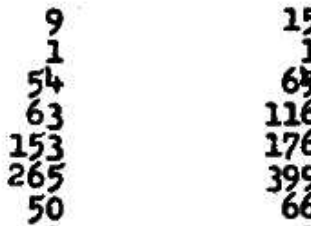

$6 \frac{5}{5}$

176

399

$\frac{1}{2}$

ii

13

56

34

1

48

44
58

19

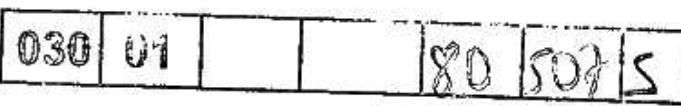




\section{8.

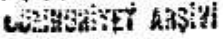

H1Ede
Ordu
R1ze
Samsun
Seyhan
S11rt
S1nop
S1vas
Tekdrdag
Tokat
Trabson
Tuncel1
Urra
Van
Yozgat
Zonguldak
Hakkari

Żrâ̂ Kombinalar

Devlet Z1.Tes.

Veteriner Is. U.Mud.

Pamuk fs. Kud.

Islah Istasyonlarx

Tarim Okwllari

Toplam ......

$$
-2-
$$

$\begin{array}{rrr}1 & 26 & 27 \\ - & - & - \\ 5 \overline{6} & -95 & \overline{81} \\ 650 & 790 & 1440 \\ 2 & 4 & 6 \\ 2 & 2 & 4 \\ 3 & 13 & 16 \\ 62 & 202 & 264 \\ 19 & 32 & 51 \\ - & 2 & 2 \\ 10 & 71 & 8 \frac{1}{10} \\ 2 & 5 & 7 \\ 14 & 5 & 17 \\ - & - & -\end{array}$

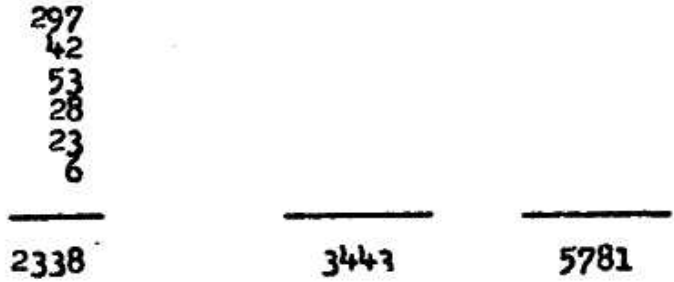

Not_.

1.- 1948 den bu gtune kadar Marshall plän1 dişında giren traktorler dahil deș11a1r.

2.- Marshall plânından 1thelâtçı f1rmalar elinde bulunup da hentiz satilmayan veya satilip da Bakanlic co sa tıs fIş1 henliz gelmiyenler dahil deşıldir,

M.k

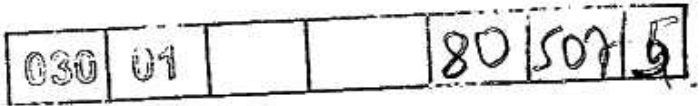




\section{Notes}

1. As shown in Appendix 2, responsive telegram written by General Alexander Marshall to Şükrü Saraçoğlu of which date was not mentioned: "Thank you on behalf of Armies under my control for your congratulatory telegram that was kind and encouraging", see TRPMA, 30.10.0.0.268.806.23. Adnan Menderes, as shown in Appendix 5, the Prime Minister, sent a kindness telegram to American authorities (General William H. Arnold and Clarence Brandal) on March 16 of 1957 for tenth anniversary of Truman Doctrine concerning their sincere wishes for Turkey, see TRPMA, 30.10.0.0.6.32.31.

2. "Marshall Plan played an important role to place ideological pre-acceptances, in particular 'foreign assistance' concept where 'intervention' phenomenon was intrinsic which was formed by modernization school after World War II and required by capitalist system could perform self production again. Moreover, Marshall Plan was mentioned as the 'assistances provided by the USA to the world' not only in the period it was announced and implemented but also for long years later on. Modernization school/development economics sub-discipline also constituted an intellectual background that feeds and reinforces ideological dimensions of Marshall Plan”, see Tören, T. 2006. "Yeniden Yapılanan Dünya Ekonomisinde Marshall Planı: Türkiye Örneği." Marmara Üniversitesi Sosyal Bilimler Enstitüsü Basılmamış Yüksek Lisans Tezi, İstanbul, p. 214. It should be remembered that at the end of World War II, role of the USA was not to develop the countries by its own resources but it was a foreign assistance or intervention, see Birinci, B. 2007. "The Marshall Plan in Turkey, a Critical Evaluation of United States' Interests in the Plan and Its Effects on the Republic.” Boğaziçi Üniversitesi Atatürk İlkeleriveİnkılap Tarihi Enstitüsü Basılmamış Yüksek Lisans Tezi, İstanbul, p. 223.

3. The first impressions of Erkin who visited General Marshall, the Minister of Foreign Affairs, on August 17 of 1948 were as the following: "I found out at first sight that I was before an especial person as soon as I entered into the bureau of him who was Chief of General Staff of American Armies in World War II, China ambassador after the victory, Minister of Foreign Affairs and former of historical Assistance Plan having his name, great soldier and statesman. There was He, as if only $\mathrm{He}$, in other opportunities appeared in Washington, in the meetings and among all the people attended these meetings. This exclusive Chief with his blue glance touching the souls, with his sweet but sharp eyes reflecting a pure heart, with his calm face having a certain power, who arouses an eternal respect on his addressee and also treats his addressee with an attentive respect, met me at the door and accepted. I can absolutely say that during seven years I spent in America I didn't see anybody else causes an effect as much as him through only his entity and peace", see, Erkin, F. C. 1992. Dışişlerinde 34 Yıl. C: II, Kısım I, Ankara, p. 6.

4. "In accordance with Mutual Assistance Agreement, although England made a commitment to provide significant amount of military assistance to Turkey, conditions were not suitable for fulfilling these commitments under the war conditions. As Turkey had a very important place in the settlements during the war and after the war, England didn't have an intention to give Turkey up. For this reason, England conducted activities in the presence of American rule and tried to make the assistances promised to give Turkey to be supplied by the USA, and it succeeded these policies. Since the beginning of the war, the USA supported its allies economically and militarily by means of Lend-Lease, Lend and Lease assistances. President Roosevelt, in a speech dated 29th December of 1940, made a statement that neutral countries could be provided with Lend-Lease assistance. After this speech, Turkey hoped to receive assistance from the USA. Hence, in the letter sent by Roosevelt to the secretary of war on 23rd March of 1941, in consequence of Turkey was important in terms of security and interests of the USA, he gave orders in direction of providing Lend-Lease assistances to that country and so it was started to prepare assistances for Turkey. Turkey became the single neutral country that took American Lend-Lease assistance out of Western world. Therefore, a new period began between American and Turkey relations. Relations were in the form of military as a matter of course and military relations developed in a short time and turned into an alliance", see, Gürbüz, M. V. Türk-Amerikan İlişkilerinde İtifak Sürecinin Başlaması. Retrieved May 13, 2017 (http://dergipark.gov.tr/download/ article-file/289162).

5. According to the essence of report submitted on May 23 of 1947 to George Marshall, the Minister of Foreign Affairs, by working group in George Kennan presidency who is the leading strategist of Planning Board, economic assistances of the USA should be started as immediate as possible and it should be based on reconstruction of Europe. According to the draft that can be summarized as Coal Program for Europe, it would be impossible to reconstruct Western Europe without restoration of Red Region and therefore German, see, Çağrı, E. Ortaya Çıkışıve Uygulanışılla Marshall Planı. Retrieved May 13, 2017 (http://dergiler. ankara.edu.tr/dergiler/42/476/5519.pdf).

6. Indeed, the English seesawed against Marshall Plan, 
although they were aware of bad side of the economic situation they experienced, and they did not want to seem like an ordinary country receiving assistances along with other countries. "They needed American economic assistance in order to put right their economies again and maintain the leadership in Commonwealth. However, this assistance was not enough to meet their demands. On the other hand, for Americans, certain issues such like money convertibility, commercial liberty were at the head of way going to economic stability and development in Europe that England was not ready for such an order. Besides, England, as a country having private bilateral relations with the USA, didn't want to be deemed as an ordinary European country. In conclusion, the Minister of English Foreign Affairs, Bevin stated that England would support the plan but would not undertake economic obligations", see Çağrı, E. Ortaya Çıkışıve Uygulanışıyla Marshall Planı. Retrieved May 13, 2017 (http://dergiler.ankara.edu.tr/dergiler/42/476/5519. pdf).

7. After Peace Treaty was signed, Italy did not consider risky to approach the USA clearly against the Soviets which assumed a tough attitude during the peace negotiations. It was worried about a civil war declared by the Russians in these countries through the communists in Italy and France. They thought to remove effect of Russians in Europe by means of Marshall Plan. Especially, even though Minister of Foreign Affairs, Kont Sforza, took important actions for political integration of Europe by enlarging the period starting with Marshall Plan, he could not be successful; the English did not approach, see, Erkin, F. C. 1987. Dışişlerinde 34 Yll. C: I, Ankara, pp. 235-239.

8. Military assistance provided by 1947 Agreement could be used only against the Soviet Union and only if America permits. Apart from that, Turkey is tied hand and foot against the threads on national security. For example, the USA did not permit in Cyprus problem. That is why it was required to wait for 10 years in order to intervene in Cyprus, see, Yetkin, Ç. 2002. Karşıdevrim 1945-1950. İstanbul, p. 356.

9. One of the important attempts setting up the infrastructure in this regard is associated to facilitate the airway transportation between two countries. Marshall, the Foreign Affairs Minister of the USA sent a friendly message to Hasan Saka, the Foreign Affairs Minister of Turkey on January 28 of 1947 due to the airway transportation starting between two countries. He indicated that it was not possible to put the Agreement of Airway Transportation into practice due to several difficulties, which it was made between these two countries on February 12 of 1946, but they did not want to delay it further and that "I thank you personally for cooperation and sympathetic understanding from your country and this new service would improve the friendly relations between Turkey and the USA". According to this, Pan America World Airways would start the new service between the USA and Turkey on January 31 by going from New York to Ankara in 33 hours, see, TRPMA, 30.10.0.0.268.806.6.

10. "Majority of the press agreed on that Turkish-American interests are common. In general, Turkish media found the Soviet policies aggressive and these policies were evaluated as having imperialist purposes. As for American assistance policies, they were comprehended as an opportunity for peace in the world and it was argued that this opportunity would bring regulation and liberty and establish the peace. Besides, American assistances were regarded as the guaranty of Turkish democracy that is one of the reasons of the general structural changes in Turkish political life. As for certain journals and magazines in the minority, they strongly criticized the format of these assistances to be practiced in the control of America in the countries received these assistances", see, Kılıç, R. 2015. "Truman Doktrinive Marshall Planı'nın Türk Basınına Yansımaları (1947-1951).” Atatürk Üniversitesi Atatürk İlkelerive İnkılap Tarihi Enstitüsü Basılmamış Yüksek Lisans Tezi, Erzurum, p. 163. And Malkoç states that America was efficiently defended in Turkish media during the American assistances after World War II. One of the major reasons of this partisanship is the Soviet pressure and the concern caused by this pressure and also thrust of America for Turkey in the cold war. "In this thrust, use of democracy and human rights statements by Americans, as they used in today's Middle East policies, is pretty remarkable in terms of showing the major slogans of the USA imperialism", see, Malkoç, E. Türk Basınında Truman Doktrinive Türkiye'ye Amerikan Yardımlarl (1947-1950). Retrieved May 13, 2017 (http://ataturkilkeler i.istanbul.edu.tr/wp-content/uploads/2013/03/ydta-09-malk oc.pdf). It is seen that in fact press organs, notably Ulus journal as the government's organ in this regard, supposed to report positive news in direction of the policies of the government. In Ulus journal, the news titled "Marshall Assistance Allocated to Turkey" on September 11 of 1948 presented based upon an American news agency with Paris origin was examined by General Directorate of Press and Publication, and it was stated that it was found inconvenient to report this news as Ulus journal was deemed as official organ of the party to which government was connected. It is stated that it was required to inform the relevant authorities on the news titled "Turkey Specified an Insincere Movement Style due to the Internal Political Reasons" involved in the news before publishing but it was not, see, TRPMA, 30.10.0.0.85.564.7.

11. The Prime Ministry was informed on that Mr. Max Weston 
Thornburg, assigned through Directorate of Press and in order to examine economic structure of Turkey in the name of "The Twentieth Century Fund" on April 26, 1947, his assistant came to the General Directorate of Statistics and that the required documents would be supplied them, see, TRPMA, 30.10.0.0.26.148.23. "Neumark Report (1949), Thornburg Report (1949-1950), Barker Report (1951), Martin and Cush Report (1951), Leimgruber Report (1951), Gruber Report (1951-52), Baade Report (1959), Chailleux-Dantel Report (1959), Giyaz Akdeniz Report (1952), Mook Report (1962), Fisher Report (1962), and Podol Report (1963) reports prepared by the experts after World War II directed development of state structure and industry in our country. It will be useful to review Truman Doctrine and approaches of the experts prepared reports for Turkey in order to comprehend better adaptation of Marshall Plan to Turkey... Thornburg Report essentially drew a parallel between the life in our and the life in the ancient times (rural) and thought that development and industrialization efforts made in that period were imported and didn't redound on large mass. In short, it introduced free market as free enterprise was prevented and was not sustained and criticized statist applications in plain English and recommended to give primacy to highway like Hilts and make progress in agriculture. Concentrating on industry, light industry consumer's goods were recommended instead of heavy industry. All the more amazing is that coal production was required to be produced and exported for Western industry instead of local industry. It stated that machine industry was unnecessary in this stage and should be delayed, and the required machine equipment (especially tractor) should be imported from the USA by means of purchase as cheaper than the production. It is required to encourage foreign capital coming and adopt a resolution. It is stated as corroborating this approach that American capital could develop Turkey. Thornburg argues against the credit asked for locomotive and tractor production. Instead of this, it recommends to perform import in a cheaper way", see, Avşaroğlu, N. Marshall Planı, Amerikan Dış Kredilerive Türkiye Madencilik Sektörüne Etkileri. Retrieved May 14, 2017 (http://www.maden.org.tr/resimler/ ekler/4cdde86a4560c17_ek.pdf?tipi=23\&turu=X\&sube=0). Avcıoglu states that the report called "Criticism on Today's Economic Situation in Turkey" prepared by economist Thornburg by examining Turkish economy in order to direct assistances of the USA is interesting, for example, this report suggests to close Karabük Iron and Steel Factories as the attempt to make locomotive; it was found meaningless as this country could not make steel sling. It argues against projects of Turkey in production of machine, plane, diesel motors, as well as tractor factories. According to Barker Report, as well, it is required to give up planned economy and etatism model, pay attention to private enterprise and foreign capital, and regulate the laws accordingly. Commercial bourgeoisie had already been strengthened by means of transition to a multi-party system acting in accordance with these American reports set to receive representative agencies of several Western companies. Under these pressures, either CHP the ruling party or DP the opposing party gave up the planned etatism based on heavy industry and adopted free entrepreneurship based on foreign capital. While Hasan Saka is the Prime Minister, plans were prepared in a hurry concerning the private enterprise and foreign capital in order to benefit from Marshall Assistance, see, Avcığlu, D. 1978. Milli Kurtuluş Tarihi 1838'den 1995'e. C: IV, Istanbul, pp. 1691-1693. It is found that the first report prepared by International Reconstruction and Development Bank prepared by the Americans (1951) had an important function to guide the following years in Turkey in the process transition from the etatism to free market economy while DP was in power, see, Albayrak, M. Uluslararası Imarve Kalkınma Bankası'nın Hazırladı̆̆ İlk Raporun (1951) Demokrat Parti Hükûmetlerinin Politikalarına Etkileri. Retrieved May 13, 2017 (http://www.atam.gov.tr/ wp-content/uploads/Mustafa-ALBAYRAK).

12. Fruits having excellent tastes grown in several regions of Turkey have an important place within the foreign trade volume. According to the statistical reports in 1935, value of the fruits exported reached up to 28.5 million liras and it was stated that $90 \%$ of which were dried grapes, figs, and hazelnuts. Although apple, apricot, watermelon, melon, grapes, plum, etc. grown in our country are pretty delicious, export amounts are limited. It is required to establish plants such like cold storages, fruit classification, packaging opportunities, etc. in order to introduce and sell them in international markets. Primary clients of our fruits are in England and Germany, see, Afetinan. 1989. Türkiye Cumhuriyetinin İkinci Sanayi Planı 1936. Ankara, p. 151.

13. Russell Door, Head of Turkish Executive Committee of Marshall Assistance, stated during the visits performed in Trabzon that it would be the best attempt to establish a fish industry in the region, see, TRPMA, 490.1.0.0.204.811.3.

14. Mustafa Kömürcü, who established a hydroelectric power plant by spending 150,000 liras through his personal enterprise in Oltu county town, Erzurum, appealed to utilize Marshall Assistance as he wanted to support it by turbine. The installation of network and turbine mentioned was examined by Provincial Directorate of Public Works and it was stated that it would be useful to support this plant that has been in service since 1948 and that increased attractions of people on the industry by enlightening county Oltu, see, 
TRPMA, 30.10.0.0.268.807.4. Council of Ministers settled on September 20, 1950 that the assistance from the several allocations to private enterprise used within the scope of Marshall Plan would be within the frame of provisions mentioned in the memorandum associated with the letter of September 7, 1950 and no. 24-D/6621 from Ministry of State, see, TRPMA, 30.18.1.2.123.72.14. It was accepted by the decision of Council of Ministry dated July 25, 1951 that 215,000 Turkish liras would be loaned to Şaban Dilaver in Erzurum from the private enterprise fund of counterpart monies within Marshall Assistance in order to import machines and equipments to be used in field irrigation, draining swamps, and the relevant works from Germany, and it was approved by Celâl Bayar, President of the Republic, see, TRPMA, 30.18.1.2.126.59.12. In the meeting conducted on June 20, 1951 by the Council of Minister, the following scripts were discussed: the script dated April 19, 1951 and no. 26-D/13981 of Organization for International Economic Cooperation in regard to granting an authority to sign Hilton agreement belonging to the hotel to be constructed in Istanbul, construct the aforementioned hotel by the Retirement Fund up to 13.5 million liras and to provide a profit guaranty of $6 \%$ by the government; dated May 11, 1951 and no. 26-D/13398 with regard to granting 215,000 Turkish liras to Şaban Dilaver in Erzurum from Marshall Assistance, in seven-year term and interest by $3 \%$, in order to import machines and equipments to be used in field irrigation, draining swamps, and the relevant works from the USA; dated May 16, 1951 and no. 26-D/14376 concerning an assistance of 1,775,000 liras by the fund of counterpart monies in order to extend the trolleybus line and also no. 26-D/15713 concerning the request for assistance in 100,000 liras in order to meet the certain deficiencies of fruit juice factory being established by Talât Kilcioğlu in Istanbul and commence the operation. Among these, requests of Şaban Dilaver and Talât Kilcioğlu were approved by the Council of Ministers, see, TRPMA, 30.18.1.2.126.59.11.

15. Cevat Dursunoğlu, deputy of Erzurum, received a negative response when he submitted the request of Head of Ağr1 CHP Provincial Administration Board for increasing agricultural implements for Ağn to the Ministry of Agriculture in the name of CHP Secretary General. Accordingly, Minister of Agriculture, Cavit Oral stated that a commission was established regarding allocation of agricultural implements and machines procured as required by the Assistance plan to the provinces and that devices to be supplied by the first shipment were distributed as tractors, harvesters, etc. by means of taking the private conditions of each province into account and then Governorates were notified in this regard. It was decided to supply two big-wheeled tractors of 35-weight horsepower, three wheeled tractors of 24-34-weight horsepower, three disc ploughs, two orchard ploughs, and one self-propelled harvester to Ağr1 province by the first shipment and it was not possible to increase in the numbers. Devices in the second shipment would be evaluated within the bounds of possibility, see, TRPMA, 490.1.0.0.134.545.4.

16. It is obvious in the writing sent by Department of the State to the Prime Ministry on September 28, 1957 that assistances would be maintained. "(2) Copies of the report no. 25 were submitted which they presented the activities of collective security assistances belonging to the term of 1.10.1955-31.12.1955 among the reports of 'Marshall Plan in Turkey' issued by the organization for International Economic Cooperation affiliated to my ministry in accordance with the law no. 5253", see, TRPMA, 30.1.0.0.62.384.9. While Marshall Plan should have been terminated at the end of 1951 under ordinary circumstances, it is seen that reports were published after 1952, as well. These reports were published under the name of "Marshall Plan in Turkey" until the end of 1959 and of "American Economic Assistances for Turkey" between 1960 and 1962. New developments appeared such like Korean War caused to prolong American assistances for Turkey. As American assistances were moved towards military as from 1952, it denotes that American assistances within the Marshall Plan ended but they were maintained for Turkey under different titles, see, Şahin, S. 2014. "Marshall Planı Ekseninde Türkiye." Karadeniz Teknik Üniversitesi Sosyal Bilimler Enstitüsü Basılmamış Yüksek Lisans Tezi, Trabzon, pp. 165-166.

17. According to the economists, this sum was equal to approximately 130 billion dollars compared to the prices in 2006. This amount was equal to approximately $5.4 \%$ of the gross national product of the USA in 1947, and according to figures in 2006, a magnitude by $5.4 \%$ in the USA economy was calculated as approximately 632 billion, see, Avşaroğlu, N. Marshall Planı, Amerikan Dış Kredilerive Türkiye Madencilik Sektörüne Etkileri. Retrieved May 14, 2017 (http://www.maden.org.tr/resimler/ekler/4cdde86a45 60c17_ek.pdf?tipi $=23 \&$ turu $=$ X\&sube $=0$ ).

18. When plan ended, a Europe was created that solved a large part of the problems between them, believed the advantages of building a single common market, and opened to cooperation. Foundation of the path to European Union was thus laid, see, Çağrı, E. Ortaya Çıkışıve Uygulanışıyla Marshall Planı. Retrieved May 13, 2017 (http://dergiler. ankara.edu.tr/dergiler/42/476/5519.pdf).

19. Village Institutes were not institutions pertaining to Turkey but they were unique institutions for Turkey. This model was implemented in several countries of the world before 
Turkey and it was discussed among the educators for nearly 40 years before implementing in Turkey. Village Institutes were not closed; they were turned into Elementary Schools and subjected to the reform process. As mentioned additionally, any document was not found during the considerably comprehensive and rich referenced study that the USA exercised pressure to close Village Institutes in return for Marshall Assistance. This claim asserted by Mahmut Aslan without merit is unable to exceed the wishes expressed by a section having left tendency, including academicians, on Village Institutes in Turkey without needing any document. For comprehensive information on this subject, see, Koç, N. 2013. Türk Kültür Tarihi İ̧erisinde Köy Enstitüleri. İstanbul.

20. "In 1951, under the effect of the USA polices, although the Government encouraged foreign investment in Turkey and made efforts for liberalism, number of the companies made investment in Turkey was only 30 in the last decade in power of DP and state had to make significant part of the investments", see, Avşaroğlu, N. Marshall Planı, Amerikan Dış Kredilerive Türkiye Madencilik Sektörüne Etkileri. Retrieved May 14, 2017 (http://www.maden.org.tr/resimler/ ekler/4cdde86a4560c17_ek.pdf?tipi=23\&turu=X\&sube=0).

21. Sum of the source reached up to $4,257,422 \mathrm{TL}$ on December 31, 1962 which was the amount accumulated in fund of Counterpart Monies and allocated to several projects. In general, public institutions, notably National Defence, utilized the Fund of Counterpart Monies. A source of 2,957,207 liras was allocated to National Defence from the aforementioned fund until December 31, 1962, and the sum of source allocated to public institutions excluding National Defence reached 916,577,000, see, Tören, T. 2006. "Yeniden Yapılanan Dünya Ekonomisinde Marshall Planı: Türkiye Örneği." Marmara Üniversitesi Sosyal Bilimler Enstitüsü Basılmamış Yüksek Lisans Tezi, İstanbul, pp. 206-207.

22. Heavy industry was founded at the period of Mustafa Kemal Atatürk in Turkey even though there was an incomparable condition compared to the developed European countries of that period, for example, Karabük Iron and Steel Factory was founded, see, Koç, N. 2011. "Türk-İngiliz Dostluğunun Tezahürü ve Karabük Demir Çelik Fabrikalarının Kuruluşu." Türk-İslâm Medeniyeti Akademik Araştırmalar Dergisi, 6(11), Konya.

23. Concerning the process to devaluation of 1958, Cahit Kayra, one of the Bureaucrats of the Ministry of Finance states that foreign debts not paid after the elections of 1954 became a problem increasingly and there was no idea how much these debts were. "Rate of dollar increases more and more in black market. Import and export descended as much as half of the figures in the previous years. Payments of three or five dollars became a problem". One dollar enhanced up to eight liras. By the way, payment plan became unsustainable in one year even though assistance was procured by 359 million dollars and payment of the debt of about 700 million dollars was suspended. When Western countries refused requests of Turkey for additional financing, although the Prime Minister Adnan Menderes tried to find a solution to provide a loan from the Soviet Union, he could not, see, Kayra, C. 1995. 1938 Kuşăgl, Olaylar, Insanlar, Anllar. İstanbul, pp. 184-186.

\section{References}

Afetinan. 1989. Türkiye Cumhuriyeti'nin İkinci Sanayi Planı 1936 (Second Industrial Plan of the Republic of Turkey 1936). Ankara: Türk Tarih Kurumu Basımevi.

Akıncı, A. and S. Usta. 2016. "Türkiye'de Çok Partili Hayata Geçişte Etkili Olan Dış Faktörlerin Değerlendirilmesi" (Assessment of the External Factors That Affect Multi Parties in Turkey). Süleyman Demirel Üniversitesi İktisadi ve İdari Bilimler Fakültesi Dergisi (Süleyman Demirel University Faculty of Economics and Administrative Sciences Journal) 21(1):275-288.

Albayrak, M. 2017. Uluslararast Imar ve Kalkinma Bankası'nın Hazırladığı Ilk Raporun (1951) Demokrat Parti Hükûmetlerinin Politikalarina Etkileri [The First Report of the International Bank for Reconstruction and Development (1951) on the Democratic Party's Politics]. Retrieved May 13, 2017 (http://www.atam.gov.tr/wpcontent/uploads/Mustafa-ALBAYRAK).

Armaoğlu, F. 1993. 20. Yüzyll Siyasi Tarihi 1914-1980 (Political History of the 20th Century 1914-1980). C: I. Ankara: Türkiye İş Bankası Kültür Yayınları.

Aslan, M. 2014. “ABD’nin İkinci Dünya Savaşı Sonrası Uyguladığı Dış Politikasının Türkiye'ye Etkileri (1945-1952)" [The Impact of the USA Foreign Policy on Turkey After World War II (1945-1952)]. Ufuk Üniversitesi Sosyal Bilimler Enstitüsü, Uluslararası İlişkiler Ana Bilim Dalı Basılmamış Yüksek Lisans Tezi (Ufuk University Institute of Social Sciences, Department of International Relations Unpublished Master Thesis), Ankara.

Avcıoğlu, D. 1978. Milli Kurtuluş Tarihi 1838'den 1995'e (National Salvation History From 1838 to 1995). C: IV. İstanbul: Tekin Yayınevi.

Avşaroğlu, N. 2008. Marshall Planı, Amerikan Dış Kredileri ve Türkiye Madencilik Sektörüne Etkileri (Marshall Plan, American Foreign Lending and the Effects on the Turkish Mining Sector). Retrieved May 14, 2017 (http://www. maden.org.tr/resimler/ekler/4cdde86a4560c17_ek.pdf?tipi= $23 \&$ turu $=$ X\&sube $=0$ ). 
Birinci B. 2007. The Marshall Plan in Turkey, a Critical Evaluation of United States' Interests in the Plan and Its Effects on the Republic. Boğaziçi Üniversitesi Atatürk İlkeleri ve İnkılap Tarihi Enstitüsü, Basılmamış Yüksek Lisans Tezi (Boğaziçi University Institute of Atatürk's Principles and History of Revolution, Unpublished Master's Thesis), İstanbul.

Bülbül, B. 2006. "Marshall Planı ve Türkiye'de Uygulanışı 1948-1957" (Marshall Plan and Its Implementation in Turkey 1948-1957). Dicle Üniversitesi Sosyal Bilimler Enstitüsü Basılmamış Yüksek Lisans Tezi (Dicle University Institute of Social Sciences Unpublished Master Thesis), Diyarbakır.

Çağrı, E. 1996. Ortaya Çıkışı ve Uygulanışıyla Marshall Planı (Marshall Plan With Outbreak and Implementation). Retrieved May 13, 2017 (http://dergiler.ankara.edu.tr/ dergiler/42/476/5519.pdf).

Çatalbaş, S. G. and N. Koç 2016. "Demokrat Parti Dönemi Kültür Politikaları (1950-1960)" [Culture Politics of Democratic Party Period (1950-1960)]. Türk-İslâm Medeniyeti Akademik Araştırmalar Dergisi (Journal of Turkish-Islamic Studies Academic Researches) 11(22):227-246.

Erkin, F. C. 1987. Dışişlerinde 34 Yll (34 Years in Foreign Affairs). C: I. Ankara: Türk Tarih Kurumu Basımevi.

—. 1992. Dışişlerinde 34 Yıl (34 Years in Foreign Affairs). C: II, Kısım I. Ankara: Türk Tarih Kurumu Basımevi.

- 1999. Dlşişlerinde 34 Yıl (34 Years in Foreign Affairs). C: II, Kısım II. Ankara: Türk Tarih Kurumu Basımevi.

Eroğul, C. 2014. Demokrat Parti Tarihi ve Ídeolojisi (Democrat Party History and Ideology). İstanbul: Yordam Kitap.

Güler, Y. 2009. “Marshall Planı ve Türkiye'de Marshall Planı'nın Uygulanışı" (Marshall Plan and the Implementation of the Marshall Plan in Turkey). Gazi Üniversitesi Sosyal Bilimler Enstitüsü Basılmamış Doktora Tezi (Gazi University Social Sciences Institute Unpublished Doctorate Thesis), Ankara.

Gürbüz, M. V. 2010. Türk-Amerikan Ilişskilerinde Itttifak Sürecinin Başlamast (Beginning of the Alliance Process in Turkish-American Relations). Retrieved May 13, 2017 (http://dergipark.gov.tr/download/article-file/289162).

Kalyon, L. 2010. Truman Doktrini Üzerine Bir Analiz (An Analysis on Truman Doctrine). Retrieved May 13, 2017 (http://dergipark.ulakbim.gov.tr/guvenlikstrtj/article/view/5 000098899/5000092155).

Kayra, C. 1995. 1938 Kuşağı, Olaylar, Insanlar, Anılar (1938 Belt, Events, People, Memoirs). İstanbul: Cem Yayınevi.

Kılıç, R. 2015. “Truman Doktrini ve Marshall Planı'nın Türk Basınına Yansımaları (1947-1951)" [Reflections to Turkish Press of Truman Doctrine and Marshall Plan (1947-1951)].
Atatürk Üniversitesi Atatürk İlkeleri ve İnkılap Tarihi Enstitüsü Basılmamış Yüksek Lisans Tezi (Atatürk University Ataturk's Principles and Revolution History Institute Unpublished Master's Thesis), Erzurum.

Koç, N. 2011. "Türk-İngiliz Dostluğunun Tezahürü ve Karabük Demir Çelik Fabrikalarının Kuruluşu" (Manifestation of Turkish-English Friendship and Establishment of Karabük Iron and Steel Plants). Türk-İslâm Medeniyeti Akademik Araştırmalar Dergisi (Journal of Turkish-Islamic Studies Academic Researches) 6(11):27-50.

—. 2013. Türk Kültür Tarihi Içerisinde Köy Enstitüleri (Village Institutes in the History of Turkish Culture). İstanbul: İdeal Kültür Yayıncılık.

Malkoç, E. 2017. Türk Basınında Truman Doktrini ve Türkiye'ye Amerikan Yardimlarl (1947-1950) [Truman Doctrine in Turkish Press and American Assistance to Turkey (1947-1950)]. Retrieved May 13, 2017 (http://ataturkilkeleri.istanbul.edu.tr/wp-content/uploads/20 13/03/ydta-09-malkoc.pdf).

Öner, S. 2006. "Labor in the U.S. Foreign Policy During Early Cold War: The Marshall Plan and American-Turkish Labor Relations 1945-1955." Bilkent Üniversitesi Ekonomi ve Sosyal Bilimler Enstitüsü Basılmamış Yüksek Lisans Tezi (Bilkent University Institute of Economics and Social Sciences Unpublished Master Thesis), Ankara.

Özer, M. H. 2014. "The Effects of the Marshall Plan Aids to the Development of the Agricultural Sector in Turkey, the 1948-1953 Period." International Journal of Economics and Financial Issues 4(2):427-439.

Şahin, S. 2014. "Marshall Planı Ekseninde Türkiye" (Turkey in the Marshall Plan Axis). Karadeniz Teknik Üniversitesi Sosyal Bilimler Enstitüsü Basılmamış Yüksek Lisans Tezi (Karadeniz Technical University Institute of Social Sciences Unpublished Master Thesis), Trabzon.

Schulberg, S. and Z. Toprak. 2008. Marshall Planı Filmleri, Mithat Alam Film Merkezi Söyleşi, Panel ve Sunum Yıllı̆̆ 2008 (Marshall Plan Films, Mithat Alam Film Center Interview, Panel and Presentation Yearbook 2008). Retrieved May 12, 2017 (http://www.mafm.boun.edu.tr/ files/111_Marshall_Plani_Filmleri.pdf).

Topal, C. 2013. Soğuk Savaşın Illk Ylllarında Türkiye-ABD İişkilerinde Ekonomik Yardımların Etkisi (The Impact of Economic Aid on Turkey-The USA Relations in the Early Years of the Cold War). Retrieved May 13, 2017 (http://www.ktu.edu.tr/dosyalar/sbedergisi_7decc.pdf).

Tören, T. 2006. "Yeniden Yapılanan Dünya Ekonomisinde Marshall Planı: Türkiye Örneği”" (Marshall Plan in the Restructured World Economy: The Case of Turkey). Marmara Üniversitesi Sosyal Bilimler Enstitüsü Basılmamış Yüksek Lisans Tezi (Marmara University Social Sciences Institute Unpublished Master Thesis), İstanbul. 


\begin{tabular}{|c|c|c|c|c|}
\hline \multicolumn{5}{|c|}{ 30.1.0.0.101.624.13. } \\
\hline $\begin{array}{r}\text { Turkish } \\
30.1 .\end{array}$ & \multicolumn{3}{|c|}{ 30.1.0.0.101.625.14. } & Archives, \\
\hline \multicolumn{5}{|c|}{ 30.1.0.0.111.700.14. } \\
\hline \multirow{7}{*}{\multicolumn{5}{|c|}{$\begin{array}{l}\text { Turkish Republic Prime Ministry Archives, } 30.1 .0 .0 .125 .801 .5 . \\
\text { Turkish Republic Prime Ministry Archives, } 30.1 .0 .0 .5 .23 .11 . \\
\text { Turkish Republic Prime Ministry Archives, } 30.1 .0 .0 .56 .344 .30 \text {. } \\
\text { Turkish Republic Prime Ministry Archives, } 30.1 .0 .0 .6 .32 .31 \text {. } \\
\text { Turkish Republic Prime Ministry Archives, } 30.1 .0 .0 .62 .384 .9 \text {. } \\
\text { Turkish Republic Prime Ministry Archives, } 30.1 .0 .0 .80 .506 .8 \text {. } \\
\text { Turkish Republic Prime Ministry Archives, } 30.1 .0 .0 .80 .507 .5 .\end{array}$}} \\
\hline & & & & \\
\hline & & & & \\
\hline & & & & \\
\hline & & & & \\
\hline & & & & \\
\hline & & & & \\
\hline $\begin{array}{r}\text { Turkish } \\
30.10\end{array}$ & \multicolumn{3}{|c|}{30.10 .0 .0 .26 .148 .23} & Archives, \\
\hline \multicolumn{5}{|c|}{ Turkish Republic Prime Ministry Archives, 30.10.0.0.268.806.23. } \\
\hline $\begin{array}{r}\text { Turkish } \\
30.10\end{array}$ & $\begin{array}{c}\text { Republic } \\
0.268 .806 .6\end{array}$ & Prime & Ministry & Archives, \\
\hline Turkish & Republic & Prime & Ministry & Archives, \\
\hline
\end{tabular}
30.10.0.0.268.807.4

Turkish Republic Prime Ministry Archives, 30.10.0.0.85.564.7.

Turkish Republic Prime Ministry Archives, 30.18.1.2.116.48.10.

Turkish Republic Prime Ministry Archives, 30.18.1.2.120.60.2.

Turkish Republic Prime Ministry Archives, 30.18.1.2.121.87.17.

Turkish Republic Prime Ministry Archives, 30.18.1.2.123.49.14.

Turkish Republic Prime Ministry Archives, 30.18.1.2.123.56.9. Turkish Republic Prime Ministry Archives,
30.18 .1 .2 .123 .72 .14

Turkish Republic Prime Ministry Archives, 30.18.1.2.126.59.11

Turkish Republic Prime Ministry Archives, 30.18.1.2.126.59.12.

Turkish Republic Prime Ministry Archives, 490.1.0.0.134.545.4.

Turkish Republic Prime Ministry Archives, 490.1.0.0.204.811.3.

Ünsal, M. 2011. Truman Doktrini ve Marshall Planı (Truman Doctrine and Marshall Plan). Retrieved February 17, 2017 (http://www.akademiktarih.com/tarih-anabilim-dal/2064-cu mhuriyet-tarihiaratrmalar/tcumhuriyeti-tarihi/28853-truman -doktrn-ve-marshall-plani.html).

Yetkin, Ç. 2002. Karşıdevrim 1945-1950 (Counter-Revolution 1945-1950). İstanbul: Otopsi Yayınevi.

Yücel, M. S. 2001. Demokrat Parti (Democratic Party). İstanbul: Ülke Kitapları.

\section{Bios}

Nurgün Koç, Ph.D., associate professor, head of Ataturk's Principles and History of Revolution Department, Faculty of Literature, head of Turkish Republican History Department, Karabük University, Turkey; research fields: modernization, Turkish modernization, history of culture, village institutes.

Bedriye Koç, graduate student, financial advisor, Department of Business Administration, Karabük University, Turkey; research fields: accounting, central banks. 